\title{
Physiological Roles for G Protein-Regulated Adenylyl Cyclase Isoforms: Insights from Knockout and Overexpression Studies
}

\author{
Rachna Sadana Carmen W. Dessauer \\ Department of Integrative Biology and Pharmacology, University of Texas Health Science Center at Houston, \\ Houston, Tex., USA
}

\section{Key Words}

Adenylyl cyclase $\cdot \mathrm{G}$ protein - Cyclic AMP - Calcium •

Synaptic plasticity $\cdot$ Cardiac function $\cdot$ Olfaction

\begin{abstract}
Cyclic AMP is a universal second messenger, produced by a family of adenylyl cyclase (AC) enzymes. The last three decades have brought a wealth of new information about the regulation of cyclic AMP production by ACs. Nine hormonesensitive, membrane-bound $A C$ isoforms have been identified in addition to a tenth isoform that lacks membrane spans and more closely resembles the cyanobacterial AC enzymes. New model systems for purifying and characterizing the catalytic domains of $A C$ have led to the crystal structure of these domains and the mapping of numerous interaction sites. However, big hurdles remain in unraveling the roles of individual $A C$ isoforms and their regulation in physiological systems. In this review we explore the latest on AC knockout and overexpression studies to better understand the roles of $\mathrm{G}$ protein regulation of $\mathrm{ACs}$ in the brain, olfactory bulb, and heart.

Copyright $\odot 2008$ S. Karger AG, Basel
\end{abstract}

\section{Introduction}

The control of second messengers involves a complex system of proteins, many or all of which are independently regulated. One of the most highly studied signal transduction pathways is the intricate control of cyclic AMP (cAMP) generation. Biochemical and genetic evidence points to roles for cAMP in a vast number of biological systems, including but not limited to oogenesis [1], embryogenesis [2], larval development, hormone secretion, glycogen breakdown [3], smooth muscle relaxation [4], cardiac contraction [5, 6], olfaction [7], and learning and memory [8-10]. Adenylyl cyclase (AC) is an ATP-pyrophosphate lyase that converts ATP to CAMP and pyrophosphate. Since the cloning of the first $\mathrm{AC}$ isoform $\mathrm{ACl}$ in 1989 [11], there has been much progress in the cloning, characterization, and structural analysis of the individual AC enzymes. Nine mammalian transmembrane ACs are recognized, with a tenth 'soluble' form that has distinct catalytic and regulatory properties resembling the cyanobacterial enzymes [12].

Numerous strategies have been developed to characterize individual AC isoforms. The assignment of regulatory properties to each isoform resulted in large part from expression of full-length AC isoforms in mammalian or insect cells (Spodoptera frugiperda, Sf9). The frustration from these systems was the lack of large amounts of pure

Carmen W. Dessauer, PhD

Department of Integrative Biology and Pharmacology

University of Texas Health Science Center at Houston

6431 Fannin Street, Houston, TX 77030 (USA)

Tel. +1 713500 6308, Fax +1 713500 7444,E-Mail carmen.w.dessauer@uth.tmc.edu 


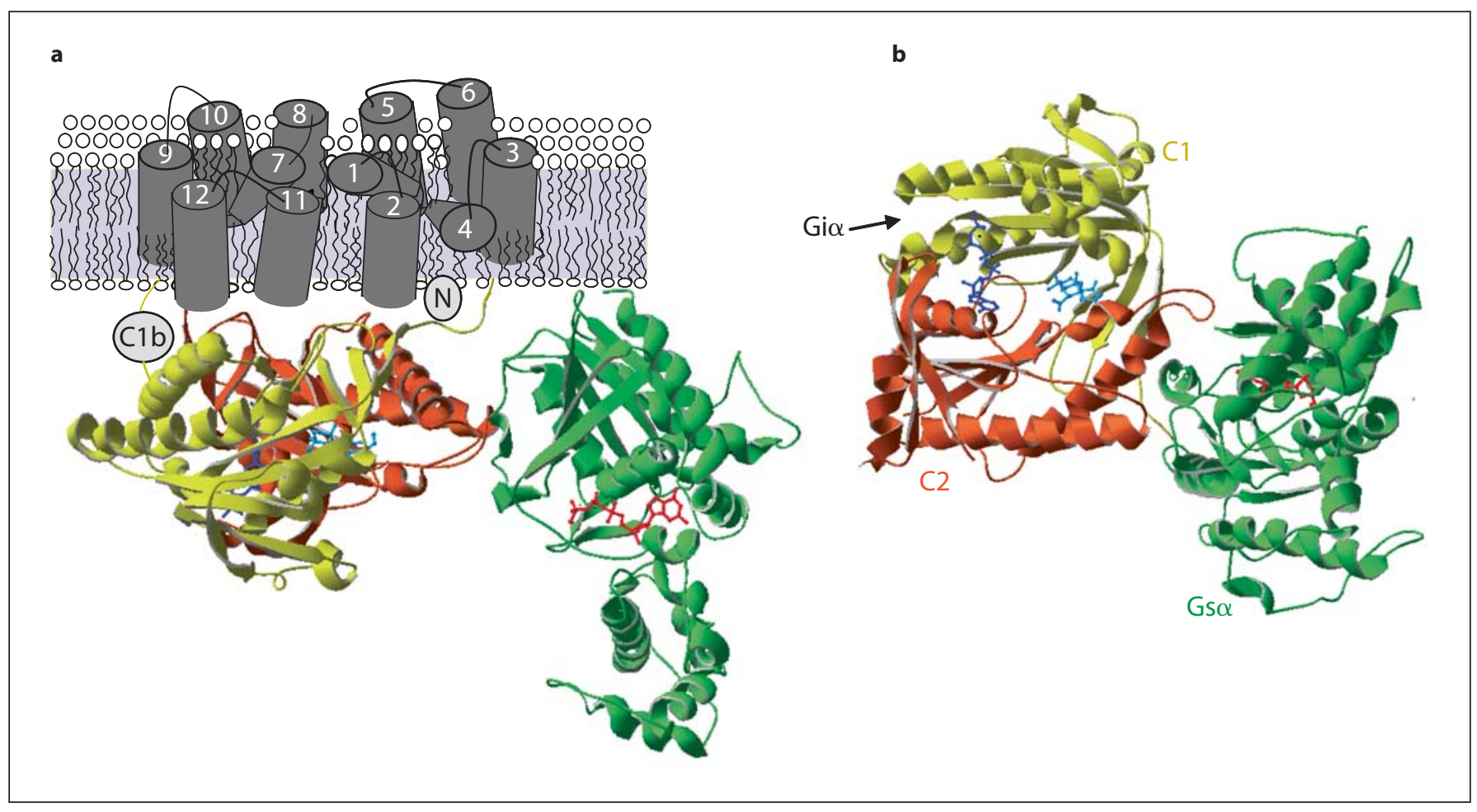

Fig. 1. Structure of adenylyl cyclase. a Crystal structure of cytoplasmic domains of AC in complex with GTP $\gamma S-G s \alpha$, forskolin (FSK) and P-site inhibitor, 2'5'-dideoxy-3'ATP [100]. Shown are C1 (yellow), C2 (rust), Gs $\alpha$ (green), FSK (cyan), and P-site inhibi- tor (dark blue). Membrane spans are modeled from the 12-membrane spanning transporters [199]. b Alternate view from cytoplasmic side, showing forskolin and catalytic site more clearly. Interaction site of $\mathrm{Gi} \alpha$ with $\mathrm{C} 1$ domain is indicated by an arrow. protein for detailed biochemical characterization. The expression of the two catalytic domains of AC in Escherichia coli largely solved this issue and resulted in sufficient protein for biochemical, kinetic, and structural studies.

Despite the progress made in the identification and biochemical characterization of cellular regulators of ACs, there are many questions that still remain unanswered. One particularly difficult question is, 'Why are there so many isoforms of $\mathrm{AC}$ and what roles do individual isoforms serve?' We will briefly review the basic structure, regulation, and tissue distribution of ACs before addressing the physiological roles of $\mathrm{AC}$ isoforms in the brain, olfactory neurons, and heart. The major focus will be on the phenotypes of $\mathrm{AC}$ knockout and overexpression studies. Although no comprehensive answers are yet available, we will attempt to address the complex issue of why unique regulatory properties of $\mathrm{AC}$ isoforms serve specific roles in cAMP biology.

\section{Adenylyl Cyclases: Topology and Structure}

Mammalian transmembrane ACs share a similar topology of a variable $\mathrm{N}$-terminus (NT) and two repeats of a membrane-spanning domain followed by a cytoplasmic domain [11]. The overall topology is very reminiscent of the $\mathrm{ABC}$ cassette transporter proteins (fig. 1). Pseudosymmetry results from the fact that each of the two cytoplasmic domains $(\mathrm{C} 1$ and $\mathrm{C} 2)$ contain a region of approximately 230 amino acid residues that are roughly $40 \%$ identical (C1a and C2a). Together the cytoplasmic domains form the catalytic moiety at their interface, creating a pseudosymmetrical site that is primed for bidirectional regulation as discussed below. The $\mathrm{NT}$ and C-terminal portion of the $\mathrm{C} 1$ and $\mathrm{C} 2$ domains ( $\mathrm{C} 1 \mathrm{~b}$ and $\mathrm{C} 2 \mathrm{~b}$ ) are the most variable regions among the different isoforms and can differ even among species.

The elegance of design, form, and function of $\mathrm{AC}$ is clearly seen in the crystal structure of the C1a-C2-Gs $\alpha$ forskolin complex [13]. The C1a and C2 domains have 
Table 1. Regulatory properties of transmembrane adenylyl cyclase (AC) isoforms

\begin{tabular}{|c|c|c|c|c|c|c|c|}
\hline \multirow[t]{2}{*}{ AC isoform } & \multicolumn{2}{|c|}{ G protein regulators } & \multicolumn{2}{|l|}{ Protein kinases } & \multirow[t]{2}{*}{ Calcium } & \multirow[t]{2}{*}{ RGS2 } & \multirow[t]{2}{*}{ Other } \\
\hline & stimulatory & inhibitory & stimulatory & inhibitory & & & \\
\hline \multicolumn{8}{|l|}{ Group I } \\
\hline $\mathrm{AC} 1$ & Gs $\alpha$ & $\mathrm{G} \alpha \mathrm{i}, \mathrm{z}, \mathrm{o}, \mathrm{G} \beta \gamma$ & $\mathrm{PKC} \alpha$ (weak) & CaMK IV & $\uparrow \mathrm{CaM}$ & & PAM \\
\hline $\mathrm{AC} 8$ & Gs $\alpha$ & $\mathrm{G} \beta \gamma$ & & & $\uparrow \mathrm{CaM}$ & & PP2A \\
\hline AC3 & $\mathrm{Gs} \alpha$ & $\mathrm{G} \beta \gamma$ & PKC $\alpha$ (weak) & CaMK II & $\uparrow \mathrm{CaM}^{*}$ & $\downarrow$ & \\
\hline \multicolumn{8}{|l|}{ Group II } \\
\hline $\mathrm{AC} 2$ & $\mathrm{Gs} \alpha, \mathrm{G} \beta \gamma$ & & $\mathrm{PKC} \alpha$ & & & & \\
\hline $\mathrm{AC} 4$ & $G s \alpha, G \beta \gamma$ & & & $\mathrm{PKC} \alpha$ & & & \\
\hline AC7 & $G s \alpha, G \beta \gamma$ & & $\mathrm{PKC} \alpha$ & & & & PAM \\
\hline \multicolumn{8}{|l|}{ Group III } \\
\hline $\mathrm{AC} 5$ & $\mathrm{Gs} \alpha, \mathrm{G} \beta \gamma$ & $\mathrm{G} \alpha \mathrm{i}, \mathrm{z}$ & $\operatorname{PKC}(\alpha, \zeta)$ & PKA & $\downarrow$ free $\mathrm{Ca}^{2+}$ & $\downarrow$ & PAM, Ric8a \\
\hline AC6 & $\mathrm{Gs} \alpha, \mathrm{G} \beta \gamma$ & $\mathrm{G} \alpha \mathrm{i}, \mathrm{z}$ & & $\mathrm{PKA}, \operatorname{PKC}(\delta, \varepsilon)$ & $\downarrow$ free $\mathrm{Ca}^{2+}$ & $\downarrow$ & PAM, Snapin \\
\hline \multicolumn{8}{|l|}{ Group IV } \\
\hline AC9 & $\mathrm{Gs} \alpha$ & & & PKC & $\downarrow$ via calcine & & \\
\hline
\end{tabular}

nearly identical tertiary structures, as predicted from their sequence similarities, despite the fact that these structures were solved with a $\mathrm{Cl}$ domain from type $5 \mathrm{AC}$ and a $\mathrm{C} 2$ domain from type $2 \mathrm{AC}$. The pseudosymmetry creates two related sites along the domain interface, a substrate-binding site and a related forskolin site. Both pockets are well defined and are structurally related. There are notable differences between the C1a and C2 structures, particularly comparing the regions that play an important role in the binding of $\mathrm{Gs} \alpha$ (C2 domain) or in the formation of a P-loop structure that binds pyrophosphate in the active site ( $\mathrm{C} 1$ domain). It is of note that the active site shares many similarities with DNA polymerases, although the surrounding structures are quite different [14].

The mammalian soluble AC (sAC) has homology to cyanobacterial ACs with several known splice variants [12]. The most studied of these are the full-length $(\sim 187$ $\mathrm{kDa})$ and the testis splice variant $(\sim 50 \mathrm{kDa})$ that contain tandem $\mathrm{C} 1$ and $\mathrm{C} 2$ domains which form the catalytic site [15]. The overall structure of the catalytic core is highly conserved with the transmembrane ACs, although there are significant differences in primary sequence [16]. Although sAC is not regulated by G proteins, it is stimulated by calcium and bicarbonate [17-19]. Our discussions of physiological roles for ACs will focus on the transmembrane ACs, although sAC has been implicated in sperm motility, fertilization, and neurite outgrowth of neuronal cells [20-22].

Physiological Roles for Adenylyl Cyclases

\section{Classification of Isoforms}

Membrane-bound ACs are often classified into four different categories based on regulatory properties. Group I consists of $\mathrm{Ca}^{2+}$-stimulated AC 1, 3 and 8; group II consists of G $\beta \gamma$-stimulated AC 2, 4 and 7; group III is comprised of $\mathrm{Gi} \alpha / \mathrm{Ca}^{2+}$-inhibited AC5 and 6, while group IV contains forskolin-insensitive AC9 (table 1). Note that although significant sequence homology exists within members of groups II and III, members of group I are more distantly related [12]. This is reflected in the overall regulatory patterns for the various groups as well.

\section{Regulation by Heterotrimeric G Proteins}

All isoforms of transmembrane ACs are stimulated by the GTP-bound $\alpha$ subunit of Gs $(\mathrm{Gs} \alpha)$. The splice variants of Gs (short, long and XL) $[23,24]$ activate AC to a similar extent in vitro, although some variations in receptor-mediated activation have been reported [25]. Golf, $\alpha$ is highly homologous to Gs $\alpha$ and also stimulates AC [26]. Golf is mainly expressed in the olfactory system but can be found in other tissues, particularly in striatum [26-29]. In both olfactory neurons and striatum, it is the Golf, $\alpha$ subunit that predominates over Gs $\alpha$ [29]. These G proteins interact with AC mainly through their switch II $\alpha$ helices, which are conforma- 
tional sensors for the $\alpha$-activation state [30]. The major binding site for Gs $\alpha$ on AC is located on the $\mathrm{C} 2$ domain in the cleft formed by $\alpha 2^{\prime}$ and $\alpha 3^{\prime}$ helices (fig. 1b) [13]. Lesser contacts are observed with the N-terminal segment of $\mathrm{C} 1$.

The $\alpha$ subunits of Gi $(1,2,3), \mathrm{Gz}$, and Go can inhibit select AC isoforms [31-33]. The calmodulin-stimulated state of $\mathrm{AC} 1$ is inhibited by all three of these Gi family members, whereas Gs $\alpha$ - or forskolin-stimulated forms of AC1 are only weakly inhibited or not at all [32]. AC5 and 6 are inhibited by $\mathrm{Gi} \alpha(1,2,3)$ and $\mathrm{Gz} \alpha$, most potently at reduced levels of activation [34]. All other ACs are insensitive to Gi $\alpha$. Mutagenesis studies show that Gi $\alpha$ binds to a cleft in the $\mathrm{C} 1$ domain [35], analogous to the Gs $\alpha$-binding site in $\mathrm{C} 2$, and acts in opposition to Gs $\alpha$.

The $\beta \gamma$ subunit of heterotrimeric $G$ proteins can be either stimulatory or inhibitory depending on the AC isoform. G $\beta \gamma$ is inhibitory for all group I ACs which include $\mathrm{AC} 1,3$, and 8 [36-38]. In the case of $\mathrm{AC} 1$, inhibition by $\mathrm{G} \beta \gamma$ is more potent than that of Gi $\alpha$ family members, which would presumably be also contributing G $\beta \gamma$ subunits [32]. When $G \beta \gamma$ is released upon activation of Gscoupled receptors, the inhibition by G $\beta \gamma$ is reported to negate AC1 and AC8 stimulation by Gs $\alpha$ in some cell types, although Gs stimulation is still synergistic with $\mathrm{Ca}^{2+} / \mathrm{CAM}$ for AC1 but not AC8 [39].

The hallmark of the AC2 family (or group II) is the conditional stimulation by G $\beta \gamma$. Gs $\alpha$-stimulated activity of AC2, 4 and 7 is enhanced by $\sim 5$ - to 10 -fold by $\mathrm{G} \beta \gamma$, although there is no effect of $G \beta \gamma$ alone $[36,40-43]$. The binding site of $\mathrm{G} \beta \gamma$ on $\mathrm{AC} 2$ has been mapped to several regions that include the $\mathrm{C} 2$ domain and the PFAHL motif in the $\mathrm{C} 1 \mathrm{~b}$ domain $[38,44]$. It is likely that $\mathrm{G} \beta \gamma$ works through a two-site interaction mechanism to regulate AC2 activity [45].

Although overexpression of G $\beta \gamma$ has been reported to lower cAMP levels in cells transfected with AC5 or 6 [46], the direct effect of G $\beta \gamma$ on these isoforms is stimulation. GB $\gamma$ binds directly to the NT of AC5 and 6 to increase $\mathrm{Gs} \alpha$-stimulated activity by approximately 2fold [47]. In fact, it is the G $\beta \gamma$ that is released upon Gs activation by isoproternol that is responsible for the full activation of AC6 [47]. Whereas for AC2 or AC7, it has been traditionally thought that $\mathrm{G} \beta \gamma$ released from $\mathrm{Gi}$ coupled receptors could synergistically stimulate AC activity in the presence of activated Gs $\alpha$, representing a form of crosstalk between $G$ protein-coupled receptors [40].

\section{Other Modes of Regulation}

\section{$\mathrm{Ca}^{2+}$ and Calmodulin}

Calcium-bound calmodulin is an important regulator of the group I ACs. AC1 and AC8 are directly stimulated by calmodulin $[48,49]$. The calmodulin-binding sites for $\mathrm{AC} 1$ have been mapped to the $\mathrm{C} 1 \mathrm{~b}$ and $\mathrm{C} 2$ domains; whereas the sites on AC8 reside within the NT and C2 domain $[50,51]$. AC3 activity is conditionally stimulated by calmodulin, requiring the presence of Gs $\alpha$ or forskolin [48]. However, the more relevant regulation of AC3 in vivo may be a calmodulin-dependent inhibition via regulation by calmodulin kinase II (CaMK II) [52]. CaMK II directly phosphorylates AC3 on ser 1076 and inhibits AC3 activity [53]. This serves as an important feedback mechanism in the olfactory system (discussed in detail later). $\mathrm{AC} 1$ is also subject to feedback inhibition via CaMK IV which phosphorylates $\mathrm{AC} 1$ within $\mathrm{C} 1 \mathrm{~b}$ and inhibits calmodulin-stimulated activity [54]. Thus both AC1 and AC3 regulation by calcium-calmodulin is tightly controlled in neuronal signaling. AC8 is not subjected to regulation by either CaMK II or IV [54].

All AC isoforms are inhibited by high, non-physiological concentrations of $\mathrm{Ca}^{2+}$, via competition for magnesium at the active site. However, AC5 and 6 are inhibited by submicromolar concentrations of free $\mathrm{Ca}^{2+}$ [55], which may have important physiological implications in generating oscillating $\mathrm{Ca}^{2+}$ and cAMP signals [56]. Curiously, these ACs respond primarily to elevations in calcium by capacitative- or store-operated calcium entry (CCE), as opposed to global increases in calcium that may be elicited by ionomycin or agonists that stimulate calcium release from the endoplasmic reticulum [for review see, 57]. Thus, ACs and CCE channels are presumed to be in close proximity on the plasma membrane. Studies using AC6 linked to the fluorescent calcium sensor aequorin are suggestive that this is indeed the case [58]. However, the identity of the CCE channels that are responsible for cAMP regulation has remained elusive. The recent identification of Stim 1 and Orail make these channels an exciting possibility for regulating AC5 and 6 by calcium [59-62].

\section{Regulation by Protein Kinases}

Most ACs are regulated by either protein kinase (PK) A or C. PKA serves as a feedback inhibitor for AC 5 and 6 by phosphorylating these isoforms on a serine near the end of the $\mathrm{Clb}$ domain [63]. PKC regulation can be either stimulatory or inhibitory. Stimulation by conventional PKCs is often highly synergistic with other forms of regulation; 
this is particularly true for AC2 and 5 [64-66]. The novel PKC $\delta$ isoform also displays synergy with Gs $\alpha$ in activating AC7 [67, 68]. Atypical forms of PKC can also stimulate AC5 [65]. PKC $\zeta$ is an atypical PKC which can be stimulated by the product of phosphoinositide-3' kinases, phosphotidylinositol-3,4,5-triphosphate. Stimulation of ACs by $\mathrm{PI} 3 \mathrm{~K} / \mathrm{PKC} \zeta$ can produce temporal effects, prolonging cAMP production and creating biphasic time courses to further enhance transcriptional responses $[69,70]$.

Inhibition by $\mathrm{PKC}$ can occur by either conventional or novel PKCs. PKC $\alpha$ inhibits Gs $\alpha$-stimulated AC4, but has no effect on basal or forskolin-stimulated activity. The novel PKC $\delta$ and $\varepsilon$ isoforms inhibit AC6 $[66,71]$. Not surprisingly, the sites of PKC phosphorylation on ACs differ greatly between these different isoforms. PKC phosphorylation sites within the C-terminus of AC2 stimulate the enzyme [72, 73], whereas phosphorylation of several sites within the NT of AC6 mediate inhibition [74, 75].

The regulation of AC9 by phosphorylation is more complex. At least 12 sites of phosphate incorporation have been detected on AC9 [76]. The mouse AC9 isoform can be inhibited by the calcium-activated protein phosphatase calcineurin (or protein phosphatase 2B) [76-78]. PKC can also inhibit AC9 activity [78-80]; however, it is unknown whether the effects by calcineurin or PKC are direct.

Additional kinases have been reported to regulate ACs. Raf1 can stimulate phosphate incorporation and activity of AC6 via activation of receptor tyrosine kinases [81]. Serines within the $\mathrm{C} 1 \mathrm{~b}$ region and the loop between membrane spans 8 and 9 are required for activation by Raf1 $[82,83]$. Tyrosine kinases such as the EGF receptor can also indirectly stimulate AC5 activity by the phosphorylation of Gs $\alpha$ [84-86]. Phosphatases would also be predicted to regulate $\mathrm{AC}$ activity and as such AC8 serves as a scaffold for PP2A [87].

\section{Forskolin and P-Site Inhibitors}

Forskolin is a diterpene derived from the root of the plant Coleus forskohlii [88]. It highly activates all the membrane-bound AC isoforms except AC9 [89, 90]. A single forskolin molecule binds at the interface of the $\mathrm{C} 1$ and $\mathrm{C} 2$ domains, in the pocket structurally related to the AC active site $[13,91]$. AC9 is missing a key residue within this forskolin-binding pocket that when mutated can restore forskolin sensitivity [92]. AC2, 4, 5, 6, and 7 are synergistically activated by Gs and forskolin, while the effect on $\mathrm{ACl}, 3$ and 8 is additive. Although tantalizing to speculate about, no mammalian forskolin analogs have been identified that might regulate ACs via the forskolinbinding pocket.

Physiological Roles for Adenylyl Cyclases
P-site inhibitors are adenosine analogs that are typically noncompetitive or uncompetitive with respect to substrate ATP [93-95]. These inhibitors are more potent on activated forms of AC versus the basal state [96-98], and form a product-like transition state with pyrophosphate $[13,99]$. More potent inhibitors, such as adenosine $3^{\prime}$-polyphosphates (i.e. $2^{\prime}, 5^{\prime}$ dideoxy $3^{\prime}$ ATP), bind in the absence of pyrophosphate since the $3^{\prime}$-phosphates bind in the pyrophosphate pocket, increasing the affinity of these inhibitors by 100 - to 1,000 -fold $[95,100]$. In general, Psite inhibitors are not greatly isoform specific with the exception of AC9, which is largely insensitive to 2 '-deoxy3'-AMP [101, 102].

\section{Additional Regulators}

Several additional regulators and binding partners of ACs exist that do not fall into any of the above categories, including the regulator of $G$ protein signaling (RGS2), the protein associated with Myc (PAM), Snapin, Ric8a, and the A-kinase-anchoring protein (AKAP79). RGS2 inhibits the activities of AC3, 5 and $6[103,104]$ and directly interacts with $\mathrm{C} 1$ domain of AC5 [105]. The PAM serves to inhibit $\mathrm{Gs} \alpha$ stimulation of $\mathrm{AC1}, 5,6$ and 7 and interacts with the C2 domain of AC5 $[106,107]$. Snapin is a member of the SNAP-25/Snare complex that physically interacts with AC6 in hippocampal neurons, preventing PKCmediated inhibition of AC6 [108]. Ric-8 is a guanine nucleotide exchange protein for heterotrimeric $G$ proteins. Ric-8a-8 binds to AC5 and inhibits activity, possibly via the activation of Gi [109]. Finally, AC5 can also bind to the PKA scaffolding protein, AKAP79, which facilitates PKA-mediated inhibition of AC5 [110]. AKAP79 may link cAMP production more closely with PKA substrates such as the NMDA receptor, bound within the same complex [111]. The regulation of AC5 and 6 by various regulators including PAM, RGS2, Snapin, and nitric oxide has recently been reviewed in depth [112].

\section{Mechanism(s) of Regulation: Interactions with Catalytic Core versus $\mathrm{N}$-Terminus}

The key to regulation of $\mathrm{AC}$ is the interface between the $\mathrm{C} 1$ and $\mathrm{C} 2$ domains which forms a single ATP-binding site $[13,91]$. Thus, many of the regulators discussed above bind to these domains to modulate enzymatic activity. The relative affinity between these domains is weak in the absence of any activators, as measured by interactions between the purified domains [113-115]. However, both forskolin and Gs $\alpha$ increase the affinity be- 
tween the $\mathrm{C} 1$ and $\mathrm{C} 2$ domains by $\sim 10$-fold; a 100 -fold increase in affinity is observed upon synergistic stimulation by both regulators [113-115]. Forskolin binds at the interface, thus it is easy to visualize its affects on domain interactions since both $\mathrm{C} 1$ and $\mathrm{C} 2$ contribute residues for binding. However, Gs $\alpha$ binds at a cleft that is on the opposite side of $\mathrm{AC}$ from the catalytic site. Comparisons with an inactive C2 homodimer suggest that Gs $\alpha$ and forskolin may induce a $7^{\circ}$ rotation of the two domains with respect to each other $[13,116]$. This movement would bring key residues in the active site closer to the 3 '-hydroxyl group of ATP, creating a conformation more favorable for catalysis [13]. Binding of $\mathrm{Gi} \alpha$ to the $\mathrm{C} 1$ domain directly opposes the actions of Gs $\alpha$ that is bound to the pseudosymmetical site in C2 [35]. Gi $\alpha$ decreases the affinity of the $\mathrm{C} 1$ and $\mathrm{C} 2$ domains for one another and inhibits catalytic activity [117]. Thus, where Gs $\alpha$ facilitates closure of the active site around ATP, Gi $\alpha$ would hinder this change and stabilize a more open inactive conformation. $\mathrm{G} \beta \gamma$ interacts with multiple domains of AC2 that would also facilitate conformational changes to cooperatively stimulate the enzyme [45]. In the fulllength enzyme the membrane spans bring together the two domains, thus the changes in relative affinity that are observed between the two domains upon stimulation likely represents these conformational changes at the domain interface.

Metal ions such as $\mathrm{Ca}^{2+}$ and $\mathrm{Mn}^{2+}$ also have effects on the catalytic site. Similar to the mechanism for DNA polymerases, AC catalyzes phosphoryl transfer by a two metal ion mechanism, which generally uses $\mathrm{Mg}^{2+}[118$, 119]. Manganese can bind to the ' $\mathrm{B}$ ' metal site to stimulate the enzyme, while calcium likely binds to the ' $\mathrm{A}$ ' metal site to inhibit the enzyme, similar to the inhibition observed with $\mathrm{Zn}^{2+}[119,120]$.

Although the $\mathrm{C} 1$ and $\mathrm{C} 2$ domains have received much of the attention, the NT clearly interacts with a number of regulators to control activity. The sequence of the NT is highly divergent, even among AC family members, and thus provides additional regulatory specificity. Studies with AC6 suggest that the NT may contact the $\mathrm{C} 1$ domain to modulate Gi $\alpha$-mediated inhibition [121]. Phosphorylation of the NT of AC6 by PKC $\delta$ and $\varepsilon$ serves to also inhibit the enzyme [71, 74, 75], whereas binding of the SNAP25-binding protein Snapin to the NT blocks PKC inhibition [108]. In addition, the NTs of both AC5 and AC6 bind GBy to conditionally stimulate the enzyme [47]. The NT of AC5 also interacts with the G protein-exchange factor RiC8a to suppress AC activity, possibly by modulating Gi activity [109]. Finally, the NT of AC8 binds protein phosphatase 2A (PP2A) [87], and forms part of the CaM-binding site to regulate activity [51]. The mechanism(s) for N-terminal regulation of ACs is unknown, but certainly opens another interesting chapter in the complex regulation of these enzymes.

\section{Physiological Roles for Individual AC Isoforms}

The question arises as to why multiple isoforms of ACs are needed and what specific functional roles are regulated by each isoform. Tissue distribution defines much of the specificity observed with respect to AC function. Due to the low abundance of AC expression and the poor antibodies available, most of the data for tissue distribution rely on PCR or Northern blotting (table 2). In many cases these patterns of expression have also been verified by functional assays based upon their differential regulatory properties. However, it is clear that most cells express two or more $\mathrm{AC}$ isoforms and nearly all $\mathrm{AC}$ isoforms are expressed in the brain. Some putative roles for ACs were initially assigned according to localization. For example, $\mathrm{AC} 1$ and 8 (primarily expressed in the brain) were ascribed roles in learning and memory; AC3 (most abundant in the olfactory epithelium) in olfaction, and AC5 and 6 (dominant in the heart) for cardiac contractility. Additional complexity arises in the expression patterns of GPCRs, G proteins, and other regulators. Due to a lack of isoform-specific inhibitors, homozygous knockout or overexpression studies of ACs have been used primarily to identify specific isoform functions. Although ACs regulate processes in all tissues, we will focus on recent studies performed in the brain, heart, and olfactory system.

\section{Synaptic Plasticity, Long-Term Potentiation, and Memory}

Synaptic plasticity is the ability of specialized connections between two neurons (i.e. synapse) to change strength. Long-term potentiation (LTP) is the long-lasting enhancement in communication between two neurons that results from stimulation. Since neurons communicate via synapses and memory is believed to be stored in synapses, LTP and long-term depression are widely considered the major cellular mechanisms that underlie learning and memory $[8,9]$. The hippocampus plays a critical role in the formation of new memories and all of the major synaptic pathways in the hippocampus exhibit LTP, including the perforant, mossy fiber 
Table 2. Tissue distribution and physiological functions of individual mammalian isoforms

\begin{tabular}{|c|c|c|c|c|}
\hline \multirow[t]{2}{*}{ AC isoforms } & \multirow[t]{2}{*}{ Site of expression } & \multicolumn{2}{|c|}{ Availability of } & \multirow[t]{2}{*}{ Physiological functions } \\
\hline & & knockout & overexpression & \\
\hline $\mathrm{AC} 1$ & Brain, adrenal medulla & Yes & & $\begin{array}{l}\text { Learning, memory, synaptic plasticity, opi- } \\
\text { ate withdrawal }\end{array}$ \\
\hline AC2 & Brain, lung, skeletal muscle, heart & & & \\
\hline AC3 & $\begin{array}{l}\text { Olfactory epithelium, pancreas, brain, } \\
\text { heart, lung, testis, BAT }\end{array}$ & Yes & & Olfaction, sperm function \\
\hline $\mathrm{AC} 4$ & Widespread & & & \\
\hline $\mathrm{AC5}$ & $\begin{array}{l}\text { Heart, striatum, kidney, liver, lung, } \\
\text { testis, adrenal, BAT }\end{array}$ & Yes & Yes $^{1}$ & $\begin{array}{l}\text { Cardiac contraction, motor coordination, } \\
\text { opiate dependency, pain responses }\end{array}$ \\
\hline AC6 & $\begin{array}{l}\text { Heart, kidney, liver, lung, brain, testis, } \\
\text { skeletal muscle, adrenal, BAT }\end{array}$ & Yes & Yes $^{1}$ & Cardiac contraction and calcium sensitivity \\
\hline $\mathrm{AC7}$ & Widespread & & Yes $^{1}$ & Ethanol dependency \\
\hline $\mathrm{AC} 8$ & Brain, lung, pancreas, testis, adrenal & Yes & Yes $^{1}$ & $\begin{array}{l}\text { Learning, memory, synaptic plasticity, opi- } \\
\text { ate withdrawal }\end{array}$ \\
\hline AC9 & Widespread & $\mathrm{Yes}^{2}$ & & \\
\hline sAC & Testis and detected in all tissues & Yes & & Sperm capacitation, fertilization \\
\hline
\end{tabular}

Sites of expression for all mammalian isoforms of AC have previously been expertly reviewed in detail [57, 176]. Expression patterns of ACs in developmental stages of mouse brain are found in Visel et al. [137].

1 Tissue-directed overexpression.

${ }^{2}$ Unpublished results [76].

and Schaffer collateral, although the mechanisms may differ.

Early studies in Drosophila and Aplysia led to the hypothesis that $\mathrm{AC}$ is involved in learning and memory. The mutant flies, dunce (phosphodiesterase activity deficient) and rutabaga (deficient in $\mathrm{Ca}^{2+} / \mathrm{CAM}$-stimulated cyclase activity) fail a number of different learning tasks, including learning to avoid a neutral odor [8]. The sequence of the rutabaga gene was most closely related to AC1 [122]. $\mathrm{AC} 1$ is primarily expressed in the brain, particularly in the hippocampus, neocortex, entorhinal cortex, cerebellar cortex, olfactory bulb and pineal gland [123, 124]. Hence it became a likely candidate for learning and memory in mammalian systems.

To further explore this notion, AC1 knockout mice $\left(\mathrm{ACl}^{(-/-)}\right)$were generated in 1995 by Wu et al. [10]. Mutant mice had normal growth, motor coordination, and lifespan. No abnormalities were observed at anatomical or morphological levels in the brain, except for a lack of barrel patterning in the sensory motor cortex [125]. However, $\mathrm{ACl}^{(--)}$mice had decreased $\mathrm{Ca}^{2+}$-stimulated $\mathrm{AC}$ ac- tivity ( $\sim 40-60 \%)$ in the cerebellum, cortex and hippocampal regions, in addition to attenuated developmental expression of $\mathrm{Ca}^{2+}$-stimulated activity $[10,126]$. The decrease in $\mathrm{Ca}^{2+}$-stimulated cAMP correlated with a decrease in CA1/CA3 hippocampal and cerebellar LTP, and a deficiency in spatial memory [10, 127]. The hippocampal defect was displayed in the early phases of LTP ( $\sim 50 \%)$, suggesting a contribution to synaptic plasticity.

A role for $\mathrm{AC} 1$ in learning and memory has been supported by additional studies in cultured anterior cingular cortex neurons, where $\mathrm{ACl}$ is essential for induction of LTP induced by Theta burst stimulation or forskolin [128]. Overexpression of $\mathrm{AC} 1$ in the forebrain enhanced recognition memory and LTP due to an enhancement of ERK/MAPK signaling [129].

$\mathrm{ACl}^{(-/-)}$mice also have impaired mossy fiber LTP, although perforant path LTP in the dentate gyrus and long lasting LTP at the Schaffer collateral are normal [130]. The impairment in mossy fiber LTP could be reversed by forskolin, indicating that the abnormality is due to an absence of $\mathrm{ACl}$ activity and not a loss of downstream sig- 
naling molecules such as PKA, ion channels, or secretory machinery. However, it is clear that $\mathrm{ACl}$ is not the only $\mathrm{AC}$ isoform important in these activities. Other AC isoforms must be present that respond to forskolin to reverse LTP defects. In addition, impairments in hippocampal and mossy fiber LTP are not complete. The most likely candidate to share overlapping functions with $\mathrm{AC} 1$ is the $\mathrm{Ca}^{2+} / \mathrm{CAM}$-stimulated AC8. AC8 is also highly expressed in numerous brain regions, including the hippocampus, olfactory bulb, thalamus, habenula, cerebellar cortex and hypothalamic supraoptic and paraventricular nuclei $[49$, 131].

AC $8^{(--)}$mice show decreased $\mathrm{Ca}^{2+}$-stimulated AC activity in the hippocampus, hypothalamus, thalamus, and brainstem, and exhibit little or no mossy fiber LTP [132, 133]. Short-term plasticity is also impaired in $\mathrm{AC}^{(-/-)}$ mice. Double knockouts of both AC1 and AC8 also exhibit a nearly complete loss of mossy fiber LTP [133]. Thus, both $\mathrm{AC} 1$ and $\mathrm{AC} 8$ contribute to mossy fiber LTP. In addition, $\mathrm{AC} 1$ and $\mathrm{AC} 8$ are functionally redundant for long-term memory and fear-associated memory formation [134]. The individual AC1 and AC8 knockouts exhibit normal L-LTP and fear-associated memory, but double knockouts were significantly impaired [134]. Infusion of forskolin in the CA1 region of the hippocampus restored normal long-term memory. Either AC1 or AC8 can generate cAMP needed for transcription-dependent long-term LTP [134].

Despite many overlapping functions, there are differences in the pathways that $\mathrm{AC} 1$ and $\mathrm{AC} 8$ control. $\mathrm{AC} 1$, but not $\mathrm{AC} 8$, is required for homeostatic plasticity during activity deprivation [135]. $\mathrm{AC}^{(-/-)}$mice show abnormal anxiety behavior under stress [132]. The latter phenotype may relate to the high expression of AC8, in the thalamus, habenula, and hypothalamus, regions involved in responses to stress. AC1 is not highly expressed in these regions [123]. Thus, AC8 is more involved in synaptic plasticity related to anxiety.

The various forms of hippocampal LTP require increases in $\mathrm{Ca}^{2+}$ either postsynaptically through NMDA receptors or presynaptically via voltage-sensitive $\mathrm{Ca}^{2+}$ channels. Perforant and Schaffer LTP are dependent on NMDA receptor activation, whereas mossy fiber/CA3 LTP likely relies on presynaptic changes in $\mathrm{Ca}^{2+}[136]$. $\mathrm{AC} 1$ and $\mathrm{AC} 8$ are expressed both presynaptically and postsynaptically [133]. The increase in $\mathrm{Ca}^{2+}$ stimulates $\mathrm{AC} 1$ and $\mathrm{AC} 8$ to generate $\mathrm{AMP}$, which in turn activates several signal transduction pathways, including PKA and Erk/MAPK via Rap-1. Erk/MAPK activates Rsk2, the major kinase for CREB. The activation of CREB/CRE transcriptional pathways leads to expression of genes required for LTP and long-term memory.

In summary, $\mathrm{AC} 1$ and $\mathrm{AC} 8$ are not necessary for survival, but play major roles in learning and memory. Although nearly all $\mathrm{AC}$ isoforms are expressed in the brain (AC4 is expressed only in the brain blood vessels) [137, 138], there are clear differences in their physiological functions. Both AC1 and AC8 are members of the $\mathrm{Ca}^{2+}$ / CAM-stimulated family of ACs, but display differences in regulatory patterns. $\mathrm{AC} 1$ has a 5 -fold lower $\mathrm{EC}_{50}$ for $\mathrm{Ca}^{2+}(150 \mathrm{nM})$ than AC8 $(800 \mathrm{nM})$ and stimulation of $\mathrm{AC} 1$, but not $\mathrm{AC} 8$, by $\mathrm{Ca}^{2+} / \mathrm{CAM}$ is synergistic with $\mathrm{Gs}$ activation [39]. In addition, $\mathrm{ACl}$ activity is enhanced by PKC [139], which is also activated during LTP [140]. Thus, $\mathrm{ACl}$ is stimulated by multiple routes for stronger synapses and in turn adapted for roles in learning and memory. But it also has several check points like inhibition by CaMK IV and Gi-coupled receptors to keep cAMP levels optimal. AC8 gene expression can be increased by CREB activation [141], but is a low-affinity $\mathrm{Ca}^{2+}$ detector with few inhibitory controls [39]. It should be mentioned that AC9 is also highly expressed in the brain, particularly the hippocampus [137]. However, genetic deletion of this isoform is embryonically lethal and thus a true assessment of the role for AC9 in brain function is not available at this time [76].

\section{Synaptic Plasticity Associated with Pain}

Pain perception is a complex trait involving peripheral and central processing, and dramatic alterations in neuronal properties induced by inflammation and injury. A clear role for cyclic AMP has been established in the sensitization of nociceptors and pain projection neurons in the spinal cord after noxious stimulation and inflammation [for review see, 142, 143]. However, the AC isoforms that contribute to these processes have only recently been studied.

$\mathrm{AC} 1$, but not $\mathrm{AC} 8$, knockout mice have significantly reduced behavioral nociceptive (pain transmission) responses of the intermediate and late phases of acute muscle pain (induced by formalin injections) [144]. In AC1 and the $\mathrm{AC} 1 / 8$ double knockouts, chronic muscle inflammatory pain (induced by carrageenan injections) was also significantly reduced but could be rescued by microinjections of forskolin in the spinal cord [144]. In addition, injection of a novel AC1 inhibitor also significantly reduced behavioral responses in both acute and chronic inflammatory muscle pain. Thus, AC1 plays an important 
role in acute and chronic muscle pain, although clearly additional ACs are present that can rescue impaired effects.

AC5 also has strong effects on acute and chronic pain responses. $\mathrm{AC} 5^{(--)}$mice have attenuated pain responses in acute thermal and mechanical pain tests [145]. They display hypoalgesic responses to inflammatory pain and inflammatory visceral pain (induced by injection of sulfate or acetic acid) [145]. AC5 $5^{(-)}$mice display strongly attenuated mechanical and thermal allodynia (an exaggerated response to normal stimuli) in neuropathic pain models. The question still remains as to where AC isoforms are exerting their effects. Pharmacological studies support the spinal cord as a major site of action [142]; $\mathrm{AC} 1$ and 5 are expressed in the spinal cord in addition to $\mathrm{AC2}, 6$, and 8 [146]. Although $\mathrm{AC} 1$ and 5 display strong differences in their regulation, both are inhibited by PAM. PAM is upregulated in the spinal cord in response to nociceptive stimulation [146] and produces a sustained inhibition in response to sphingosine-1-phosphate [147], a regulator of neuronal cell survival [148]. In summary, these studies support roles for $\mathrm{AC} 1$ and 5, but not AC8 in synaptic plasticity related to different forms of pain.

\section{Excitotoxicity and Neurodegeneration}

Excitotoxicity is the pathological process by which nerve cells are damaged and killed by glutamate or similar substances. When NMDA or AMPA receptors are overactivated, neuronal death ensues via an influx of $\mathrm{Ca}^{2+}$ leading to apoptosis. Knockout of $\mathrm{AC} 1$ significantly attenuated neuronal cell death induced by intracortical injections of NMDA, but deletion of AC8 had no such effect [149]. Thus, $\mathrm{Ca}^{2+}$-stimulated $\mathrm{ACl}$ modulates neuronal responses to excitotoxicity and may serve as a novel target for treatment of neuronal excitotoxicity in stroke and neurodegenerative disease.

Ethanol can also induce neurodegeneration in the brains of neonatal mice, which can be mimicked by NMDA receptor antagonists or potentiators of the GABA receptor. Genetic deletion of $\mathrm{AC} 1, \mathrm{AC} 8$ or both isoforms enhanced ethanol- or phenobarbital-induced neurodegeneration, but not cell death due to hypoxia/ ischemia [150]. Therefore AC1 alone controls neuronal death in response to NMDA-dependent excitotoxicity, while both $\mathrm{AC} 1$ and 8 may play important roles in neurodegeneration induced by activity blockade in the neonatal brain.

Physiological Roles for Adenylyl Cyclases

\section{Motor Functions}

The striatum is the region of brain important for the planning and programming of voluntary movements, as well as some cognitive functions. These functions involve dopamine receptor signaling. $\mathrm{ACl}$ and 8 have no effects on motor coordination [144]. However, AC5 is highly enriched in the striatum and genetic ablation of AC5 shows a reduction in forskolin-stimulated activity in the striatum $(>80 \%)$, cerebral cortex $(\sim 27 \%)$, and cerebellum (40\%) [151]. Only $10 \%$ of dopamine D1-stimulated AC activity and $16 \%$ of adenosine A2A-stimulated AC activity remain in the striatum of $\mathrm{AC}^{(-/-)}$mice, while the dopamine D2 inhibition of AC activity mediated by Gi is completely absent $[138,151]$. General motor behavior is normal in $\mathrm{AC5} 5^{(-/)}$mice; however, these mice show loss of neuroleptic responsiveness towards the D2 antagonist class of antipsychotic drugs [151]. Other AC5 $5^{(-)}$models exhibit Parkinson-like motor dysfunction, displaying abnormal coordination, bradykinesia, and locomotor impairment [138]. Motor coordination can be restored by D2 stimulation, while bradykinesia was largely restored by either D1 or D2 stimulation of residual striatal AC activity. Although AC6 and AC1 (the other Gi-inhibited ACs) are present in the striatum, they cannot fully compensate for AC5 function [138]. AC5 is the physiological isoform coupled to dopamine $\mathrm{D} 2$ receptors and plays an important role in the response to antipsychotic drugs. AC5 provides a site of convergence for both D1 and D2 dopaminergic signals and the inhibition of AC5 by Gi $\alpha$ is a crucial regulatory property for CAMP-dependent motor control.

\section{Drug Dependence (Morphine, Ethanol)}

\section{Morphine}

Opiate-induced analgesia is mediated by the activation of Gi-coupled $\mu$, and to a lesser extent by $\delta$-opioid receptors. Their analgesic properties are related to the inhibition of $\mathrm{AC}$, inhibition of voltage-gated $\mathrm{Ca}^{2+}$, and activation of inward rectifying $\mathrm{K}^{+}$channels by $\mathrm{Gi}[152,153]$. The inhibition of $\mathrm{AC}$ has been linked to long-term adaptations by opiates. Long-term morphine use causes an upregulation of $\mathrm{AC}$ signal transduction components (AC, PKA, or CREB) in regions of the brain associated with drug reinforcement and withdrawal [153]. In cell culture systems, AC supersensitization can be measured after treatment with Gi-coupled ligands (such as morphine, muscarinic agents, and somatostatin). The increase in AC 
activity is long-lived, appears to require $G \beta \gamma$ subunits (although not in a direct regulatory role of AC), and is specific for the AC1, 5, 6, and 8 isoforms [154-156].

$\mathrm{AC} 1$ and 8 are upregulated by long-term exposure to morphine, and genetic deletion of AC1 and 8 caused a significant reduction in withdrawal behaviors including reduced shakes and forepaw tremors after naloxone injection [157]. The AC1/8 knockout mice had less morphine-induced hyper-locomotion and conditioned place preference; although the latter effect may be due to impairments in learning and memory. CREB activation induced by morphine was not evident in the $\mathrm{ACl} / 8$ double knockout mice in the ventral tegmental area. Gene expression patterns after chronic morphine administration in $\mathrm{AC} 1$ or 8 knockouts were only partially overlapping in the locus coeruleus (a region critical for opioid withdrawal), providing additional evidence that these $\mathrm{AC}$ isoforms have distinct functions during chronic morphine exposure [158]. $\mathrm{Ca}^{2+}$-stimulated cyclases (AC1 and 8) are important mediators of morphine responses but not the only required $\mathrm{AC}$ isoforms.

AC5 has also been reported to be an essential mediator of morphine action within striatum [159]. The $\mu$-opioid receptors are at their highest level in the striatum and implicated in reward mechanisms [160]. AC5 is the primary $\mathrm{AC}$ effector for $\mu$ - and $\delta$-opioid receptors in the striatum, with deletion of AC5 resulting in a loss of opioid-induced inhibition of AC activity in the striatum [159]. All the major behavioral effects of morphine, including locomotor activation, analgesia, tolerance, reward and physiological dependence, and withdrawal symptoms, were attenuated in AC5 KO mice. These behavioral effects were selective for $\mu$ - and $\delta$-opioid receptor agonists; $\kappa$-dependent locomotor activity was unaffected.

The roles of cAMP in morphine dependence have been further evaluated by overexpression of AC7 in the mouse brain, resulting in the enhancement of acute and chronic actions of morphine [161]. In this model, tolerance to morphine develops more rapidly than in wildtype mice. Thus it is clear that cAMP signaling is important in opioid dependency with $\mathrm{AC} 1$ and 8 playing roles in withdrawal, hyper-locomotion, and the learned responses to morphine; whereas AC5 is involved in all major behavioral effects of morphine, including analgesia, locomotor, reward, tolerance, and withdrawal.

\section{Ethanol}

As discussed previously, ethanol acts as a neuroactive agent by antagonizing NMDA or potentiating the effects of GABA. Both in drosophila and mice, the sedative effects of ethanol are due to a decrease in cAMP signaling. $\mathrm{AC} 1$ knockouts or the knockout of both $\mathrm{AC} 1$ and 8 display enhanced sensitivity to the sedative but not ataxic effects of ethanol [162]. The effect on sedation was minimal for the deletion of $\mathrm{AC} 8$ alone, but $\mathrm{AC} 8^{(-/-)}$had decreased voluntary ethanol consumption that was not observed in the $\mathrm{ACl}^{(-/)}$mice.

An increase in cAMP (by overexpression of AC7) resulted in high levels of phosphorylated DARPP32 (a dopamine- and cAMP-regulated phosphoprotein) which has been implicated in the motivational effects of ethanol [163]. AC7 is indirectly stimulated 2- to 3 -fold by ethanol or morphine, but the role of AC7 in alcohol dependence may be more prominent in platelets rather than in the brain where AC7 is expressed at lower levels (mainly the cerebellar granule layer) [164]. In fact, AC7 activity in platelets has been proposed to be a trait marker for alcoholism $[165,166]$.

\section{Olfactory Signaling}

Odorants interact with $\mathrm{G}$ protein-coupled receptors to stimulate AC via Golf. Cylic AMP directly binds to cyclic nucleotide gated channels (CNG) causing an influx of cations (largely $\mathrm{Ca}^{2+}$ and some $\mathrm{Na}^{+}$) and a small depolarization of olfactory neurons. $\mathrm{Ca}^{2+}$ influx opens $\mathrm{Ca}^{2+}-\mathrm{ac}-$ tivated chloride channels, to further polarize the neuron, triggering an action potential. The olfactory system is composed of two subsystems: the main olfactory epithelium (responsible for odorant detection) and the vomeronasal system (responsible for pheromone detection). Although AC2, 3 and 4 are expressed in the olfactory system, AC3 is the predominant isoform [7]. AC3, Golf, and CNG channels have not been detected in the vomeronasal system; instead AC2 predominates [167].

Genetic deletion of AC3 confirms a role in olfaction [7]. $\mathrm{AC} 3^{(-/-)}$mice were initially runts but later gained weight comparable to their wild-type littermates. The initial growth defect is likely due to the fact that $\mathrm{AC}^{(-/-)}$ mice do not detect mouse milk [168]. Deletion of AC3 had major effects on odorant-induced signaling. Responses to cAMP- or IP3-inducing odorants were completely ablated in $\mathrm{AC} 3^{(-/)}$mice as measured by electro-olfactograms, and olfactory epithelial membranes lacked stimulation to the mouse pheromone, 2-heptanone. However, some volatile odorants could be detected by the vomeronasal system, independent of AC3 [169], consistent with a role of $\mathrm{AC} 2$ or another AC in this system. 
Deletion of AC3 also gave rise to impairments in olfactory-dependent learning and olfaction-based behavioral tests, signifying a critical role for AC 3 and cAMP in these processes. In addition, $\mathrm{AC} 3^{(--)}$mice do not detect mouse urine or pheromones and inter-male aggressiveness and male sexual behavior is absent [168]. AC3 also appears to be responsible for spermatozoa function and male fertility [170]. In general the vomeronasal organ is thought to be responsible for pheromone detection; however, it is clear that the olfactory epithelium and $\mathrm{AC} 3$ are also associated with these activities.

Finally, the absence of AC3 perturbed the peripheral olfactory projections in mice and the establishment of mature glomerular [171]. AC3 represents a pivotal element in odorant-mediated axonal guidance, sorting, and identity, and its deletion results in a modified olfactory bulb topographical map and prevents expression of the major axon guidance molecule, neuropilin-1 [172].

AC3 regulatory patterns are adapted for a role in olfaction. AC3 is strongly stimulated by Golf and displays feedback regulation from CaMKII and RGS2. CAMKII is activated in response to increased CNG-dependent $\mathrm{Ca}^{2+}$ influx and mediates a rapid feedback inhibition of AC3 [173]. RGS2 negatively regulates odorant-evoked intracellular signaling of olfactory neurons [103], and may give rise to a longer adaptation since it is upregulated in response to cAMP and $\mathrm{Ca}^{2+}[174,175]$.

\section{Cardiac Function}

Sympathetic stimulation in the heart leads to an increase in AC activity, resulting in PKA activation and the phosphorylation of numerous effectors including L-type $\mathrm{Ca}^{2+}$ channels, phospholamban, and troponin-I. These PKA substrates are involved in cardiac contractility, $\mathrm{Ca}^{2+}$ uptake, and cardiac relaxation. Heart expresses all isoforms except AC8 $[57,176]$ (AC1 is only in the sino-atrial node [177]). AC5 and 6 are the major isoforms expressed in cardiac myocytes and have been the focus of several deletion and overexpression studies outlined below.

Two independent strains of $\mathrm{AC} 5^{(-/)}$mice have been generated with similar decreases in AC activity. The disruption of the AC5 gene leads to decreased basal and stimulated (isoproterenol and forskolin) activity ( $~ 35$ $40 \%)$ in cardiac membranes and isolated myocytes [5, 178]. However, differences have been reported between the strains in terms of cardiac function. Okumura et al. [5] reported no change in basal cardiac function in $\mathrm{AC} 5^{(-I)}$ (with intravenous isoproterenol), but the isopro- terenol-stimulated left ventricular (LV) ejection fraction was significantly decreased [5]. In a second $\mathrm{AC} 5^{(-/-)}$model by Tang et al. [178], basal contractile function was increased in isolated perfused hearts, but with decreased sensitivity to a $\beta_{1}$-adrenergic receptor agonist although the maximal levels were unchanged. However, a significant reduction in Gs $\alpha$ protein $(\sim 60 \%)$ was reported in the latter model [178], whereas no differences in G protein, receptor, or AC levels were reported by Okumura et al. [5].

The greatest effect of AC5 deletion is on parasympathetic regulation of cAMP. Deletion of AC5 results in a complete loss of acetylcholine-mediated (Gi) inhibition and a significant reduction in $\mathrm{Ca}^{2+}$-mediated inhibition of cAMP production [5]. This corresponded with a reduction in the effects of muscarinic agonists on LV ejection fraction and heart rate in $\mathrm{AC} 5^{(-/)}$mice. Baroreflexes were also attenuated. These effects on parasympathetic regulation of cardiac function may partially explain the odd increase in basal heart rates observed in $\mathrm{AC}^{(-/-)}$ mice $[5,178]$.

Chronic activation of cAMP signaling by overexpression of $\beta-A R, G s \alpha$, or PKA results in cardiomyopathy [179-181]. Thus limiting cAMP under stress conditions should be beneficial. Certainly the use of $\beta$-blockers for the treatment of congestive heart failure is consistent with this notion. Similarly, disruption of AC5 under stress conditions (pressure overload by thoracic banding) is protective against heart failure, potentially by increasing Bcl-2 and reducing myocardial apoptosis [182]. AC5 disruption protects against other forms of stress as well. AC5 ${ }^{(-/)}$mice have increased lifespan $(\sim 30 \%)$ and are protected against age-induced cardiac myopathy (which includes hypertrophy, apoptosis, fibrosis, and reduced cardiac function) [183]. AC5 disruption leads to a stimulation of the Raf/MEK/ERK pathway and an upregulation of superoxide dismutase, which may play roles in extending lifespan and resistance to oxidative stress [183].

The deletion of AC6 results in a somewhat different phenotype from that of AC5. Both isoforms are expressed equally at birth but in adult heart AC5 is dominant [184, 185]. Deletion of type $6 \mathrm{AC}$ [186] resulted in no change in cAMP levels under basal conditions but cAMP levels were reduced by $\sim 60 \%$ in left ventricular homogenates and by $\sim 70 \%$ in cardiac myocytes under stimulated conditions. In addition, cardiac myocytes from $\mathrm{AC}^{(-/-)}$show reductions in PKA activity (40\%), Akt activity (60\%), phospholamban phosphorylation (45\%), and $\beta A R$-stimulated LV contractile function $(\sim 80 \%)$. The more severe decreases in AC activity and cAMP signaling compared 
to $\mathrm{AC} 5^{(-/-)}$are likely due to a dramatic decrease in AC5 protein levels by proteosomal degradation, although AC5 mRNA levels were unchanged. Thus these animals represent a functional double knockout of AC5 and AC6. Conclusions can still be made about roles for AC6 from these animals, particularly in regard to calcium handling. Deletion of AC6 decreased the $\mathrm{Ca}^{2+}$ affinity of SERCA2a by 3.5 -fold and reduced caffeine-stimulated $\mathrm{Ca}^{2+}$ transients by $50 \%$. These properties cannot be attributed to the decrease in AC5, since a small increase (not decrease) in $\mathrm{Ca}^{2+}$ uptake was observed in $\mathrm{AC}^{(-/-)}$ [178].

Overexpression of AC5, 6 and 8 has been examined in the heart with somewhat differing results. Overexpression of AC5 in wild-type mice led to increased basal cAMP, PKA activity, phosphorylated phospholamban, and baseline heart rates, without an enhancement of $\beta$ adrenergic receptor signaling or changes in global cardiac function [187, 188]. While in mice overexpressing AC6, basal heart rate and contractile function were unchanged, but cardiac responsiveness to $\beta 2$-adrenergic receptor stimulation was increased [189]. In pigs, intracoronary delivery of an adenovirus expressing AC6 increases global LV contractile function with increased $\beta_{2-}$ adrenergic receptor responsiveness and LV contractile function [190]. What is unclear in these overexpression models is whether the differences observed between AC5 and 6 point to abnormal coupling of these isoforms to various signaling pathways or an enhancement of their physiological roles in the heart.

Overexpression of AC8 enhanced AC activity 7- to 8fold in cardiac membranes, increased basal PKA activity, and displayed $\mathrm{Ca}^{2+}$-stimulation [191]. $\mathrm{Ca}^{2+}$-stimulated AC8 is not normally expressed in the heart, yet AC8 overexpression had no deleterious effects on global cardiac function. Basal contractile rates and cardiac function (as measured by echocardiography) were unchanged despite elevated cAMP $[188,191]$. However, recordings using cardiac catheterization or in isolated perfused hearts, measured a 2 -fold increase in cardiac contractility under basal conditions $[188,191,192]$, but no response to $\beta_{2}$-adrenergic receptor stimulation [191]. AC8 overexpression resulted in an increased $\mathrm{Ca}^{2+}$ sensitivity to cardiac contraction and faster SR uptake of $\mathrm{Ca}^{2+}$, but no increase in L-type $\mathrm{Ca}^{2+}$ whole cell current [192]. These changes likely mediate the increased exercise capacity on treadmill testing by mice overexpressing AC8.

Paradoxically, overexpression studies paint a very different picture concerning the roles of cAMP in heart failure. Although AC5 deletion is protective against heart failure (in thoracic banding models), overexpression of AC5 or 6 improves survival rates in Gq-overexpression models. Overexpression of Gq is a cardiomyopathy model and leads to a decrease in cardiac responsiveness to catecholamines, reduced LV function, and decreased survival rates. Overexpression of AC5 or 6 improves these markers of heart failure, restoring basal cardiac AC activity, cardiac contractility, cardiac responsiveness to catecholamine stimulation, and survival rates [187, 193-195]. During congestive heart failure in pigs, AC6 overexpression increases LV function and attenuates deleterious LV modeling [196]. These studies suggest a beneficial role for AC5 and 6 in the pathogenesis of heart failure which is in contrast to the AC5 knockout.

In summary, AC5 and 6 are very closely related AC isoforms in terms of stimulation by Gs $\alpha$ and G $\beta \gamma$ and inhibition by $\mathrm{Ca}^{2+}$ and PKA. The differences in Gi $\alpha$ regulation are subtle in that basal activity of AC5, but not AC6, is inhibited by Gi $\alpha$ [34]. Both isoforms are more sensitive to Gi $\alpha$ inhibition when weakly stimulated by Gs $\alpha$; with increasing activation resulting in decreased Gi $\alpha$ inhibition. The other major difference is in PKC regulation. AC5 is stimulated by PKC ( $\alpha$ and $\zeta$ ), while AC6 is inhibited by PKC ( $\delta$ and $\varepsilon$ ). Thus both isoforms are highly regulated with numerous inhibitory inputs to carefully control cAMP levels. Cyclic AMP produced by endogenous AC5 may be harmful under stress conditions such as heart failure or aging; however, both AC5 and 6 overexpression can mitigate harmful effects of Gq overexpression. Clearly the heart has many ways to finely control the production and utility of cAMP.

\section{Conclusions}

Although AC expression patterns dictate much of the observed specificity in controlling physiological functions, clearly the regulation of individual $\mathrm{AC}$ isoforms is also an important factor. Another manner in which cAMP production may be fine-tuned for specific signaling pathways is by the creation of cAMP microdomains [197] or the formation of higher-order signaling complexes [111]. The latter strategy likely involves the use of Akinase anchoring proteins to directly tether cAMP production to downstream effector molecules. This has recently been shown for AC5 and AKAP79, where complexes have been detected in rat brain tissue [110]. This complex facilitates phosphorylation of AC5 and sets up a negative feedback loop for cAMP production. Several strategies have been proposed for the creation of cAMP 
microdomains or gradients, including diffusional barriers for cAMP, enzymatic barriers created by phosphodiesterases, or buffering of cAMP by PKA [57, 198]. Finally, the lipid composition of the plasma membrane itself may guide the formation of specific complexes either within or excluded from regions of high cholesterol and sphingolipids; all but AC2, 4, and 7 have been found within lipid rafts [for review see, 57]. Finally, the question of overlapping functions of ACs is still difficult to determine. The very nature of knockout and overexpression studies leads to the possibility of compensation at many levels. Without isoform-specific AC inhibitors and/or high quality specific AC antibodies, there are many open questions left to answer with regard to the physiological roles for distinct $\mathrm{AC}$ isoforms.

\section{Acknowledgments}

The authors wish to thank Dr. Edgar (Terry) Walters for his critical review of the manuscript and the National Institute of Health (GM60419) for funding.

\section{References}

1 Burton KA, McKnight GS: PKA, germ cells, and fertility. Physiology 2007;22:40-46.

-2 Bellen HJ, Gregory BK, Olsson CL, Kiger JA: Two drosophila learning mutants, dunce and rutabaga, provide evidence of a maternal role for cAMP on embryogenesis. Dev Biol 1987;121:432-444.

3 Hardman JG, Robison GA, Sutherland EW: Cyclic nucleotides. Annu Rev Physiol 1971; 33:311-336.

4 Andersson R, Nilsson K: Cyclic amp and calcium in relaxation in intestinal smooth muscle. Nat New Biol 1972;238:119-120.

5 Okumura S, Kawabe J, Yatani A, Takagi G, Lee MC, Hong C, Liu J, Takagi I, Sadoshima J, Vatner DE, Vatner SF, Ishikawa Y: Type 5 adenylyl cyclase disruption alters not only sympathetic but also parasympathetic and calcium-mediated cardiac regulation. Circ Res 2003;93:364-371.

6 Post SR, Hammond HK, Insel PA: Beta-adrenergic receptors and receptor signaling in heart failure. Annu Rev Pharmacol Toxicol 1999;39:343-360.

7 Wong ST, Trinh K, Hacker B, Chan GC, Lowe G, Gaggar A, Xia Z, Gold GH, Storm DR: Disruption of the type III adenylyl cyclase gene leads to peripheral and behavioral anosmia in transgenic mice. Neuron 2000; 27:487-497.

8 Davis RL, Cherry J, Dauwalder B, Han PL, Skoulakis E: The cyclic amp system and drosophila learning. Mol Cell Biochem 1995; 149-150:271-278.

$\checkmark 9$ Kandel ER: The molecular biology of memory storage: a dialogue between genes and synapses. Science 2001;294:1030-1038.

$10 \mathrm{Wu}$ ZL, Thomas SA, Villacres EC, Xia Z, Simmons ML, Chavkin C, Palmiter RD, Storm DR: Altered behavior and long-term potentiation in type I adenylyl cyclase mutant mice. Proc Natl Acad Sci USA 1995;92: 220-224.
Krupinski J, Coussen F, Bakalyar HA, Tang WJ, Feinstein PG, Orth K, Slaughter C, Reed RR, Gilman AG: Adenylyl cyclase amino acid sequence: possible channel- or transporter-like structure. Science 1989;244: 1558-1564.

$\checkmark 12$ Kamenetsky M, Middelhaufe S, Bank EM, Levin LR, Buck J, Steegborn C: Molecular details of cAMP generation in mammalian cells: a tale of two systems. J Molec Biol 2006; 362:623-639.

13 Tesmer JJ, Sunahara RK, Gilman AG, Sprang SR: Crystal structure of the catalytic domains of adenylyl cyclase in a complex with Gsalpha.GTPgammaS. Science 1997;278: 1907-1916

14 Sinha SC, Sprang SR: Structures, mechanism, regulation and evolution of class III nucleotidyl cyclases. Rev Physiol Biochem Pharmacol 2006;157:105-140.

15 Buck J, Sinclair ML, Schapal L, Cann MJ, Levin LR: Cytosolic adenylyl cyclase defines a unique signaling molecule in mammals. Proc Natl Acad Sci USA 1999;96:79-84.

16 Steegborn C, Litvin TN, Levin LR, Buck J, Wu H: Bicarbonate activation of adenylyl cyclase via promotion of catalytic active site closure and metal recruitment. Nat Struct Mol Biol 2005;12:32-37.

17 Chen Y, Cann MJ, Litvin TN, Iourgenko V, Sinclair ML, Levin LR, Buck J: Soluble adenylyl cyclase as an evolutionarily conserved bicarbonate sensor. Science 2000;289:625628.

18 Jaiswal BS, Conti M: Calcium regulation of the soluble adenylyl cyclase expressed in mammalian spermatozoa. Proc Natl Acad Sci USA 2003;100:10676-10681.

19 Litvin TN, Kamenetsky M, Zarifyan A, Buck J, Levin LR: Kinetic properties of 'soluble' adenylyl cyclase. Synergism between calcium and bicarbonate. J Biol Chem 2003;278: 15922-15926.
20 Esposito G, Jaiswal BS, Xie F, Krajnc-Franken MA, Robben TJ, Strik AM, Kuil C, Philipsen RL, van Duin M, Conti M, Gossen JA: Mice deficient for soluble adenylyl cyclase are infertile because of a severe sperm-motility defect. Proc Natl Acad Sci USA 2004;101: 2993-2998.

21 Wu KY, Zippin JH, Huron DR, Kamenetsky M, Hengst U, Buck J, Levin LR, Jaffrey SR: Soluble adenylyl cyclase is required for netrin-1 signaling in nerve growth cones. Nat Neurosci 2006;9:1257-1264.

22 Xie F, Garcia MA, Carlson AE, Schuh SM, Babcock DF, Jaiswal BS, Gossen JA, Esposito G, van Duin M, Conti M: Soluble adenylyl cyclase (sac) is indispensable for sperm function and fertilization. Dev Biol 2006;296: 353-362.

23 Bray P, Carter A, Simons C, Guo V, Puckett C, Kamholz J, Spiegel A, Nirenberg M: Human cDNA clones for four species of Galpha $\mathrm{s}$ signal transduction protein. Proc Natl Acad Sci 1986;83:8893-8897.

24 Kehlenbach RH, Matthey J, Huttner WB: Xl alpha $s$ is a new type of $G$ protein. Nature 1994;372:804-809.

25 Klemke M, Pasolli HA, Kehlenbach RH, Offermanns S, Schultz G, Huttner WB: Characterization of the extra-large $\mathrm{G}$ protein alpha-subunit XLalphas. II. Signal transduction properties. J Biol Chem 2000;275: 33633-33640.

26 Jones DT, Reed RR: Golf: An olfactory neuron specific-g protein involved in odorant signal transduction. Science 1989;244:790795.

27 Itakura S, Ohno K, Ueki T, Sato K, Kanayama N: Expression of Golf in the rat placenta: possible implication in olfactory receptor transduction. Placenta 2006;27:103-108.

28 Ferrand N, Pessah M, Frayon S, Marais J, Garel JM: Olfactory receptors, Golf alpha and adenylyl cyclase mRNA expressions in the rat heart during ontogenic development. J Mol Cell Cardiol 1999;31:1137-1142. 
-29 Herve D, Levi-Strauss M, Marey-Semper I, Verney C, Tassin JP, Glowinski J, Girault JA: $\mathrm{G}($ olf) and Gs in rat basal ganglia: possible involvement of G(olf) in the coupling of dopamine D1 receptor with adenylyl cyclase. J Neurosci 1993;13:2237-2248.

-30 Sprang SR, Chen Z, Du X, Stephen RS: Structural basis of effector regulation and signal termination in heterotrimeric Galpha proteins. Adv Protein Chem 2007;74:1-65.

-31 Taussig R, Iniguez-Lluhi JA, Gilman AG: Inhibition of adenylyl cyclase by $\mathrm{Gi}$ alpha. Science 1993;261:218-221.

-32 Taussig R, Tang WJ, Hepler JR, Gilman AG: Distinct patterns of bidirectional regulation of mammalian adenylyl cyclases. J Biol Chem 1994;269:6093-6100.

-33 Kozasa T, Gilman AG: Purification of recombinant $\mathrm{G}$ proteins from $\mathrm{Sf} 9$ cells by hexahistidine tagging of associated subunits. Characterization of alpha 12 and inhibition of adenylyl cyclase by alpha z. J Biol Chem 1995;270:1734-1741.

34 Chen-Goodspeed M, Lukan AN, Dessauer CW: Modeling of Galpha(s) and Galpha(i) regulation of human type $\mathrm{v}$ and vi adenylyl cyclase. J Biol Chem 2005;280:1808-1816.

\35 Dessauer CW, Tesmer JJ, Sprang SR, Gilman AG: Identification of a Gialpha binding site on type $\mathrm{V}$ adenylyl cyclase. J Biol Chem 1998; 273:25831-25839.

-36 Tang WJ, Gilman AG: Type-specific regulation of adenylyl cyclase by $G$ protein beta gamma subunits. Science 1991;254:15001503.

-37 Steiner D, Saya D, Schallmach E, Simonds WF, Vogel Z: Adenylyl cyclase type-VIII activity is regulated by $\mathrm{G}$ (betagamma) subunits. Cell Signal 2006;18:62-68.

\38 Diel S, Klass K, Wittig B, Kleuss C: Gbetagamma activation site in adenylyl cyclase type II. Adenylyl cyclase type III is inhibited by Gbetagamma. J Biol Chem 2006;281:288294.

-39 Nielsen MD, Chan GC, Poser SW, Storm DR: Differential regulation of type I and type VIII $\mathrm{Ca}^{2+}$-stimulated adenylyl cyclases by Gi-coupled receptors in vivo. J Biol Chem 1996;271:33308-33316.

-40 Federman AD, Conklin BR, Schrader KA, Reed RR, Bourne HR: Hormonal stimulation of adenylyl cyclase through Gi-protein beta gamma subunits. Nature 1992;356:159161.

41 Taussig R, Quarmby LM, Gilman AG: Regulation of purified type I and type II adenylylcyclases by $\mathrm{G}$ protein beta gamma subunits. J Biol Chem 1993;268:9-12.

-42 Iniguez-Lluhi JA, Simon MI, Robishaw JD, Gilman AG: G protein beta gamma subunits synthesized in Sf9 cells. Functional characterization and the significance of prenylation of gamma. J Biol Chem 1992;267: 23409-23417.
43 Bayewitch ML, Avidor-Reiss T, Levy R, Pfeuffer T, Nevo I, Simonds WF, Vogel Z: Differential modulation of adenylyl cyclases I and II by various Gbeta subunits. J Biol Chem 1998;273:2273-2276.

-44 Weng G, Li J, Dingus J, Hildebrandt JD, Weinstein H, Iyengar R: Gbeta subunit interacts with a peptide encoding region 956-982 of adenylyl cyclase 2. Cross-linking of the peptide to free Gbeta gamma but not the heterotrimer. J Biol Chem 1996;271:2644526448.

45 Diel S, Beyermann M, Navarro Llorens JM, Wittig B, Kleuss C: Two interaction sites on mammalian adenylyl cyclase type I and II: modulation by calmodulin and G(betagamma). Biochem J 2008;411:449456.

46 Bayewitch ML, Avidor-reiss T, Levy R, Pfeuffer T, Nevo I, Simonds WF, Vogel Z: Inhibition of adenylyl cyclase isoforms $\mathrm{V}$ and VI by various Gbetagamma subunits. FASEB J 1998;12:1019-1025.

47 Gao X, Sadana R, Dessauer CW, Patel TB: Conditional stimulation of type $\mathrm{V}$ and $\mathrm{VI}$ adenylyl cyclases by $\mathrm{G}$ protein betagamma subunits. J Biol Chem 2007;282:294-302.

48 Choi EJ, Xia Z, Storm DR: Stimulation of the type III olfactory adenylyl cyclase by calcium and calmodulin. Biochemistry 1992;31: 6492-6498.

49 Cali JJ, Zwaagstra JC, Mons N, Cooper DM, Krupinski J: Type VIII adenylyl cyclase. A $\mathrm{Ca}^{2+} /$ calmodulin-stimulated enzyme expressed in discrete regions of rat brain. J Biol Chem 1994;269:12190-12195.

$50 \mathrm{Gu}$ C, Cooper DM: Calmodulin-binding sites on adenylyl cyclase type VIII. J Biol Chem 1999;274:8012-8021.

51 Simpson RE, Ciruela A, Cooper DMF: The role of calmodulin recruitment in $\mathrm{Ca}^{2+}$ stimulation of adenylyl cyclase type 8. J Biol Chem 2006;281:17379-17389.

52 Wayman GA, Impey S, Storm DR: $\mathrm{Ca}^{2+}$ inhibition of type III adenylyl cyclase in vivo. J Biol Chem 1995;270:21480-21486.

53 Wei J, Wayman G, Storm DR: Phosphorylation and inhibition of type III adenylyl cyclase by calmodulin-dependent protein $\mathrm{ki}$ nase II in vivo. J Biol Chem 1996;271: 24231-24235.

54 Wayman GA, Wei J, Wong S, Storm DR: Regulation of type I adenylyl cyclase by calmodulin kinase IV in vivo. Mol Cell Biol 1996;16: 6075-6082.

55 Guillou JL, Nakata H, Cooper DM: Inhibition by calcium of mammalian adenylyl cyclases. J Biol Chem 1999;274:35539-35545.

56 Cooper DM, Brooker G: $\mathrm{Ca}^{2+}$-inhibited adenylyl cyclase in cardiac tissue. Trends Pharmacol Sc 1993;14:34-36.

57 Willoughby D, Cooper DM: Organization and $\mathrm{Ca}^{2+}$ regulation of adenylyl cyclases in cAMP microdomains. Physiol Rev 2007;87: 965-1010.
58 Nakahashi Y, Nelson E, Fagan K, Gonzales E, Guillou JL, Cooper DM: Construction of a full-length $\mathrm{Ca}^{2+}$-sensitive adenylyl cyclase/ aequorin chimera. J Biol Chem 1997;272: 18093-18097.

59 Peinelt C, Vig M, Koomoa DL, Beck A, Nadler MJ, Koblan-Huberson M, Lis A, Fleig A, Penner R, Kinet JP: Amplification of CRAC current by STIM1 and CRACM1 (Orai1). Nat Cell Biol 2006;8:771-773.

60 Soboloff J, Spassova MA, Tang XD, Hewavitharana T, Xu W, Gill DL: Orail and STIM reconstitute store-operated calcium channel function. J Biol Chem 2006;281:2066120665.

61 Mercer JC, DeHaven WI, Smyth JT, Wedel B, Boyles RR, Bird GS, Putney JW Jr: Large store-operated calcium selective currents due to co-expression of Orail or Orai2 with the intracellular calcium sensor, stim1. J Biol Chem 2006;281:24979-24990.

62 Zhang SL, Yeromin AV, Zhang XH, Yu Y, Safrina O, Penna A, Roos J, Stauderman KA, Cahalan MD: Genome-wide RNAi screen of $\mathrm{Ca}^{2+}$ influx identifies genes that regulate $\mathrm{Ca}^{2+}$ release-activated $\mathrm{Ca}^{2+}$ channel activity. Proc Natl Acad Sci USA 2006;103:93579362.

63 Iwami G, Kawabe J, Ebina T, Cannon PJ, Homcy CJ, Ishikawa Y: Regulation of adenylyl cyclase by protein kinase A. J Biol Chem 1995;270:12481-12484.

64 Jacobowitz O, Iyengar R: Phorbol ester-induced stimulation and phosphorylation of adenylyl cyclase 2. Proc Natl Acad Sci USA 1994;91:10630-10634.

65 Kawabe J, Iwami G, Ebina T, Ohno S, Katada T, Ueda Y, Homcy CJ, Ishikawa Y: Differential activation of adenylyl cyclase by protein kinase C isoenzymes. J Biol Chem 1994;269: 16554-16558.

-66 Zimmermann G, Taussig R: Protein kinase $\mathrm{C}$ alters the responsiveness of adenylyl cyclases to $G$ protein alpha and betagamma subunits. J Biol Chem 1996;271:2716127166.

67 Haslauer M, Baltensperger K, Porzig H: Thrombin and phorbol esters potentiate Gsmediated camp formation in intact human erythroid progenitors via two synergistic signaling pathways converging on adenylyl cyclase type VII. Mol Pharmacol 1998;53: 837-845

68 Nelson EJ, Hellevuo K, Yoshimura M, Tabakoff B: Ethanol-induced phosphorylation and potentiation of the activity of type 7 adenylyl cyclase. Involvement of protein kinase C delta. J Biol Chem 2003;278:4552-4560.

69 Nguyen BT, Dessauer CW: Relaxin stimulates protein kinase $\mathrm{C}$ zeta translocation: requirement for cyclic adenosine $3^{\prime}, 5^{\prime}$-monophosphate production. Mol Endocrinol 2005;19:1012-1023. 
70 Dessauer CW, Nguyen BT: Relaxin stimulates multiple signaling pathways: activation of cAMP, PI3K, and PKCzeta in THP-1 cells. Ann NY Acad Sci 2005;1041:272-279.

71 Lai HL, Yang TH, Messing RO, Ching YH, Lin SC, Chern Y: Protein kinase C inhibits adenylyl cyclase type VI activity during desensitization of the A2a-adenosine receptormediated cAMP response. J Biol Chem 1997; 272:4970-4977.

-72 Bol GF, Gros C, Hulster A, Bosel A, Pfeuffer T: Phorbol ester-induced sensitisation of adenylyl cyclase type II is related to phosphorylation of threonine 1057. Biochem Biophys Res Commun 1997;237:251-256.

73 Bol GF, Hulster A, Pfeuffer T: Adenylyl cyclase type II is stimulated by $\mathrm{PKC}$ via c-terminal phosphorylation. Biochim Biophys Acta 1997;1358:307-313.

74 Lai HL, Lin TH, Kao YY, Lin WJ, Hwang MJ, Chern Y: The $n$ terminus domain of type VI adenylyl cyclase mediates its inhibition by protein kinase C. Mol Pharmacol 1999;56: 644-650.

-75 Lin TH, Lai HL, Kao YY, Sun CN, Hwang MJ, Chern Y: Protein kinase C inhibits type VI adenylyl cyclase by phosphorylating the regulatory $\mathrm{n}$ domain and two catalytic $\mathrm{cl}$ and c2 domains. J Biol Chem 2002;277: 15721-15728.

76 Antoni FA: Adenylyl cyclase type 9. UCSDNature Molecule Pages 2006.

-77 Antoni FA, Barnard RJO, Shipston MJ, Smith SM, Simpson J, Paterson JM: Calcineurin feedback inhibition of agonist-evoked cAMP formation. J Biol Chem 1995;270:2805528061.

78 Antaraki A, Ang KL, Antoni FA: Involvement of calyculin A inhibitable protein phosphatases in the cyclic amp signal transduction pathway of mouse corticotroph tumour (att20) cells. Br J Pharmacol 1997;121:991999.

-79 Antoni FA, Sosunov AA, Haunso A, Paterson JM, Simpson J: Short-term plasticity of cyclic adenosine 3',5'-monophosphate signaling in anterior pituitary corticotrope cells: the role of adenylyl cyclase isotypes. Mol Endocrinol 2003;17:692-703.

80 Cumbay MG, Watts VJ: Novel regulatory properties of human type 9 adenylate cyclase. J Pharmacol Exp Ther 2004;310:108115.

81 Ding Q, Gros R, Gray ID, Taussig R, Ferguson SS, Feldman RD: Raf kinase activation of adenylyl cyclases: isoform-selective regulation. Mol Pharmacol 2004;66:921-928.

-82 Tan CM, Kelvin DJ, Litchfield DW, Ferguson SS, Feldman RD: Tyrosine kinase-mediated serine phosphorylation of adenylyl cyclase. Biochemistry 2001;40:1702-1709.

83 Beazely MA, Alan JK, Watts VJ: Protein kinase $C$ and epidermal growth factor stimulation of raf1 potentiates adenylyl cyclase type 6 activation in intact cells. Mol Pharmacol 2005;67:250-259.
84 Nair BG, Parikh B, Milligan G, Patel TB: Gs alpha mediates epidermal growth factorelicited stimulation of rat cardiac adenylate cyclase. J Biol Chem 1990;265:21317-21322.

85 Poppleton H, Sun H, Fulgham D, Bertics P, Patel TB: Activation of Gsalpha by the epidermal growth factor receptor involves phosphorylation. J Biol Chem 1996;271: 6947-6951.

86 Yu Y, Nair BG, Patel TB: Epidermal growth factor stimulates cAMP accumulation in cultured rat cardiac myocytes. J Cell Physiol 1992;150:559-567.

87 Crossthwaite AJ, Ciruela A, Rayner TF, Cooper DMF: A direct interaction between the $n$ terminus of adenylyl cyclase AC8 and the catalytic subunit of protein phosphatase $2 \mathrm{a}$. Mol Pharmacol 2006;69:608-617.

88 Seamon KB, Daly JW: Forskolin: its biologi$\mathrm{cal}$ and chemical properties. Adv Cyclic $\mathrm{Nu}$ cleotide Protein Phosphorylation Res 1986; 20:1-150.

89 Sutkowski EM, Tang WJ, Broome CW, Robbins JD, Seamon KB: Regulation of forskolin interactions with type I, II, V, and VI adenylyl cyclases by Gs alpha. Biochemistry 1994; 33:12852-12859.

90 Hacker BM, Tomlinson JE, Wayman GA, Sultana R, Chan G, Villacres E, Disteche C, Storm DR: Cloning, chromosomal mapping, and regulatory properties of the human type 9 adenylyl cyclase (adcy9). Genomics 1998; 50:97-104.

91 Dessauer CW, Scully TT, Gilman AG: Interactions of forskolin and ATP with the cytosolic domains of mammalian adenylyl cyclase. J Biol Chem 1997;272:22272-22277.

$\$ 92$ Yan SZ, Huang ZH, Andrews RK, Tang WJ: Conversion of forskolin-insensitive to forskolin-sensitive (mouse-type IX) adenylyl cyclase. Mol Pharmacol 1998;53:182-187.

$\$ 93$ Desaubry L, Johnson RA: Adenine nucleoside 3 '-tetraphosphates are novel and potent inhibitors of adenylyl cyclases. J Biol Chem 1998;273:24972-24977.

94 Dessauer CW, Tesmer JJ, Sprang SR, Gilman AG: The interactions of adenylate cyclases with P-site inhibitors. Trends Pharmacol Sci 1999;20:205-210.

95 Desaubry L, Shoshani I, Johnson RA: Inhibition of adenylyl cyclase by a family of newly synthesized adenine nucleoside $3^{\prime}$-polyphosphates. J Biol Chem 1996;271:1402814034.

96 Wolff J, Londos C, Cooper DM: Adenosine receptors and the regulation of adenylate $\mathrm{cy}$ clase. Adv Cyclic Nucleotide Res 1981;14: 199-214

97 Florio VA, Ross EM: Regulation of the catalytic component of adenylate cyclase. Potentiative interaction of stimulatory ligands and 2',5'-dideoxyadenosine. Mol Pharmacol 1983;24:195-202.
-98 Johnson RA, Yeung SM, Stubner D, Bushfield M, Shoshani I: Cation and structural requirements for $\mathrm{P}$ site-mediated inhibition of adenylate cyclase. Mol Pharmacol 1989;35:681-688.

-99 Dessauer CW, Gilman AG: The catalytic mechanism of mammalian adenylyl cyclase. Equilibrium binding and kinetic analysis of P-site inhibition. J Biol Chem 1997;272:27787-27795.

100 Tesmer JJ, Dessauer CW, Sunahara RK, Murray LD, Johnson RA, Gilman AG, Sprang SR: Molecular basis for P-site inhibition of adenylyl cyclase. Biochemistry 2000;39:14464-14471.

-101 Johnson RA, Desaubry L, Bianchi G, Shoshani I, Lyons E Jr, Taussig R, Watson PA, Cali JJ, Krupinski J, Pieroni JP, Iyengar R: Isozyme-dependent sensitivity of adenylyl cyclases to P-site-mediated inhibition by adenine nucleosides and nucleoside $3^{\prime}$ polyphosphates. J Biol Chem 1997;272: 8962-8966.

102 Haunso A, Simpson J, Antoni FA: Small ligands modulating the activity of mammalian adenylyl cyclases: a novel mode of inhibition by calmidazolium. Mol Pharmacol 2003;63:624-631.

103 Sinnarajah S, Dessauer CW, Srikumar D, Chen J, Yuen J, Yilma S, Dennis JC, Morrison EE, Vodyanoy V, Kehrl JH: RGS2 regulates signal transduction in olfactory neurons by attenuating activation of adenylyl cyclase III. Nature 2001;409:1051-1055.

104 Roy AA, Baragli A, Bernstein LS, Hepler JR, Hebert TE, Chidiac P: RGS2 interacts with Gs and adenylyl cyclase in living cells. Cell Signal 2006;18:336-348.

105 Salim S, Sinnarajah S, Kehrl JH, Dessauer CW: Identification of RGS2 and type V adenylyl cyclase interaction sites. J Biol Chem 2003;278:15842-15849.

106 Scholich K, Pierre S, Patel TB: Protein associated with Myc (PAM) is a potent inhibitor of adenylyl cyclases. J Biol Chem 2001; 276:47583-47589.

107 Gao X, Patel TB: Histidine residues 912 and 913 in protein associated with Myc are necessary for the inhibition of adenylyl cyclase activity. Mol Pharmacol 2005;67:42-49.

108 Chou Jl, Huang CL, Lai HL, Hung AC, Chien CL, Kao YY, Chem Y: Regulation of type VI adenylyl cyclase by Snapin, a SNAP25-binding protein. J Biol Chem 2004;279:46271-46279.

109 Wang SC, Lai HL, Chiu YT, Ou R, Huang CL, Chem Y: Regulation of type V adenylate cyclase by Ric8a, a guanine nucleotide exchange factor. Biochem J 2007;406:383388.

110 Bauman AL, Soughayer J, Nguyen BT, Willoughby D, Carnegie GK, Wong W, Hoshi N, Langeberg LK, Cooper DM, Dessauer CW, Scott JD: Dynamic regulation of cAMP synthesis through anchored PKA-adenylyl cyclase V/VI complexes. Mol Cell 2006;23: 925-931. 
111 Wong W, Scott JD: Akap signalling complexes: focal points in space and time. Nat Rev Mol Cell Biol 2004;5:959-970.

-112 Beazely MA, Watts VJ: Regulatory properties of adenylate cyclases type 5 and 6: a progress report. Eur J Pharmacol 2006;535: $1-12$.

- 113 Whisnant RE, Gilman AG, Dessauer CW: Interaction of the two cytosolic domains of mammalian adenylyl cyclase. Proc Natl Acad Sci USA 1996;93:6621-6625.

114 Yan SZ, Hahn D, Huang ZH, Tang WJ: Two cytoplasmic domains of mammalian adenylyl cyclase form a Gs alpha- and forskolin-activated enzyme in vitro. J Biol Chem 1996;271:10941-10945.

- 115 Sunahara RK, Dessauer CW, Whisnant RE, Kleuss C, Gilman AG: Interaction of Gsalpha with the cytosolic domains of mammalian adenylyl cyclase. J Biol Chem 1997;272: 22265-22271.

116 Zhang G, Liu Y, Qin J, Vo B, Tang WJ, Ruoho AE, Hurley JH: Characterization and crystallization of a minimal catalytic core domain from mammalian type II adenylyl cyclase. Protein Sci 1997;6:903-908.

117 Dessauer CW, Chen-Goodspeed M, Chen J: Mechanism of Galpha i-mediated inhibition of type $\mathrm{V}$ adenylyl cyclase. J Biol Chem 2002;277:28823-28829.

-118 Mitterauer T, Hohenegger M, Tang WJ, Nanoff C, Freissmuth M: The c2 catalytic domain of adenylyl cyclase contains the second metal ion (Mn2+) binding site. Biochemistry 1998;37:16183-16191.

-119 Tesmer JJ, Sunahara RK, Johnson RA, Gosselin G, Gilman AG, Sprang SR: Two-metal-Ion catalysis in adenylyl cyclase. Science 1999;285:756-760.

-120 Hu B, Nakata H, Gu C, de Beer T, Cooper DMF: A critical interplay between $\mathrm{Ca}^{2+}$ inhibition and activation by $\mathrm{Mg}^{2+}$ of $\mathrm{AC} 5$ revealed by mutants and chimeric constructs. J Biol Chem 2002;277:33139-33147.

121 Kao YY, Lai HL, Hwang MJ, Chem Y: An important functional role of the $\mathrm{N}$ terminus domain of type VI adenylyl cyclase in Galphai-mediated inhibition. J Biol Chem 2004;279:34440-34448.

- 122 Levin LR, Han PL, Hwang PM, Feinstein PG, Davis RL, Reed RR: The drosophila learning and memory gene rutabaga encodes a $\mathrm{Ca}^{2+} /$ calmodulin-responsive adenylyl cyclase. Cell 1992;68:479-489.

- 123 Xia Z, Choi EJ, Wang F, Blazynski C, Storm DR: Type I calmodulin-sensitive adenylyl cyclase is neural specific. J Neurochem 1993;60:305-311.

124 Tzavara ET, Pouille Y, Defer N, Hanoune J: Diurnal variation of the adenylyl cyclase type 1 in the rat pineal gland. Proc Natl Acad Sci USA 1996;93:11208-11212.
125 Abdel-Majid RM, Leong WL, Schalkwyk LC, Smallman DS, Wong ST, Storm DR, Fine A, Dobson MJ, Guernsey DL, Neumann PE: Loss of adenylyl cyclase I activity disrupts patterning of mouse somatosensory cortex. Nat Genet 1998;19:289-291.

126 Villacres EC, Wu Z, Hua W, Nielsen MD, Watters JJ, Yan C, Beavo J, Storm DR: Developmentally expressed $\mathrm{Ca}(2+)$-sensitive adenylyl cyclase activity is disrupted in the brains of type I adenylyl cyclase mutant mice. J Biol Chem 1995;270:14352-14357.

127 Storm DR, Hansel C, Hacker B, Parent A, Linden DJ: Impaired cerebellar long-term potentiation in type I adenylyl cyclase mutant mice. Neuron 1998;20:1199-1210.

128 Liauw J, Wu LJ, Zhuo M: Calcium-stimulated adenylyl cyclases required for longterm potentiation in the anterior cingulate cortex. J Neurophysiol 2005;94:878-882.

129 Wang H, Ferguson GD, Pineda VV, Cundiff PE, Storm DR: Overexpression of type-1 adenylyl cyclase in mouse forebrain enhances recognition memory and LTP. Nat Neurosci 2004;7:635-642.

130 Villacres EC, Wong ST, Chavkin C, Storm DR: Type I adenylyl cyclase mutant mice have impaired mossy fiber long-term potentiation. J Neurosci 1998;18:3186-3194.

131 Muglia LM, Schaefer ML, Vogt SK, Gurtner G, Imamura A, Muglia LJ: The 5'-flanking region of the mouse adenylyl cyclase type VIII gene imparts tissue-specific expression in transgenic mice. J Neurosci 1999;19: 2051-2058.

132 Schaefer ML, Wong ST, Wozniak DF, Muglia LM, Liauw JA, Zhuo M, Nardi A, Hartman RE, Vogt SK, Luedke CE, Storm DR, Muglia LJ: Altered stress-induced anxiety in adenylyl cyclase type VIII-deficient mice. J Neurosci 2000;20:4809-4820.

133 Wang H, Pineda VV, Chan GC, Wong ST, Muglia LJ, Storm DR: Type 8 adenylyl cyclase is targeted to excitatory synapses and required for mossy fiber long-term potentiation. J Neurosci 2003;23:9710-9718.

134 Wong ST, Athos J, Figueroa XA, Pineda VV, Schaefer ML, Chavkin CC, Muglia LJ, Storm DR: Calcium-stimulated adenylyl cyclase activity is critical for hippocampusdependent long-term memory and late phase LTP. Neuron 1999;23:787-798.

135 Gong B, Wang H, Gu S, Heximer SP, Zhuo $\mathrm{M}$ : Genetic evidence for the requirement of adenylyl cyclase 1 in synaptic scaling of forebrain cortical neurons. Eur J Neurosci 2007;26:275-288.

136 Zalutsky RA, Nicoll RA: Comparison of two forms of long-term potentiation in single hippocampus neurons. Correction. Science 1991;251:856.

-137 Visel A, Alvarez-Bolado G, Thaller C, Eichele G: Comprehensive analysis of the expression patterns of the adenylate cyclase gene family in the developing and adult mouse brain. J Comp Neurol 2006;496: 684-697.
138 Iwamoto T, Okumura S, Iwatsubo K, Kawabe J, Ohtsu K, Sakai I, Hashimoto Y, Izumitani A, Sango K, Ajiki K, Toya Y, Umemura S, Goshima Y, Arai N, Vatner SF, Ishikawa Y: Motor dysfunction in type 5 adenylyl cyclase-null mice. J Biol Chem 2003;278:16936-16940.

139 Choi EJ, Wong ST, Dittman AH, Storm DR: Phorbol ester stimulation of the type I and type III adenylyl cyclases in whole cells. Biochemistry 1993;32:1891-1894.

-140 Kleschevnikov AM, Routtenberg A: PKC activation rescues LTP from NMDA receptor blockade. Hippocampus 2001;11:168175.

141 Chao JR, Ni YG, Bolanos CA, Rahman Z, DiLeone RJ, Nestler EJ: Characterization of the mouse adenylyl cyclase type VIII gene promoter: regulation by CAMP and CREB. Eur J Neurosci 2002;16:1284-1294.

142 Skyba DA, Radhakrishnan R, Bement MK, Sluka KA: The cAMP pathway and pain: potential targets for drug development. Drug Discovery Today: Disease Models 2004;1:115-119.

143 Hucho T, Levine JD: Signaling pathways in sensitization: toward a nociceptor cell biology. Neuron 2007;55:365-376.

144 Vadakkan KI, Wang H, Ko SW, Zastepa E, Petrovic MJ, Sluka KA, Zhuo M: Genetic reduction of chronic muscle pain in mice lacking calcium/calmodulin-stimulated adenylyl cyclases. Mol Pain 2006;2:7.

145 Kim KS, Kim J, Back SK, Im JY, Na HS, Han PL: Markedly attenuated acute and chronic pain responses in mice lacking adenylyl cyclase-5. Genes Brain Behav 2007;6:120127.

146 Ehnert C, Tegeder I, Pierre S, Birod K, Nguyen HV, Schmidtko A, Geisslinger G, Scholich K: Protein associated with Myc (PAM) is involved in spinal nociceptive processing. J Neurochem 2004;88:948957.

147 Pierre SC, Hausler J, Birod K, Geisslinger G, Scholich K: PAM mediates sustained inhibition of cAMP signaling by sphingosine-1phosphate. EMBO J 2004;23:3031-3040.

148 Edsall LC, Pirianov GG, Spiegel S: Involvement of sphingosine 1-phosphate in nerve growth factor-mediated neuronal survival and differentiation. J Neurosci 1997; 17: 6952-6960.

149 Wang H, Gong B, Vadakkan KI, Toyoda H, Kaang BK, Zhuo M: Genetic evidence for adenylyl cyclase 1 as a target for preventing neuronal excitotoxicity mediated by $\mathrm{N}$ methyl-D-aspartate receptors. J Biol Chem 2007;282:1507-1517.

150 Maas JW Jr, Indacochea RA, Muglia LM, Tran TT, Vogt SK, West T, Benz A, Shute AA, Holtzman DM, Mennerick S, Olney JW, Muglia LJ: Calcium-stimulated adenylyl cyclases modulate ethanol-induced neurodegeneration in the neonatal brain. J Neurosci 2005;25:2376-2385. 
-151 Lee KW, Hong JH, Choi IY, Che Y, Lee JK, Yang SD, Song CW, Kang HS, Lee JH, Noh JS, Shin HS, Han PL: Impaired D2 dopamine receptor function in mice lacking type 5 adenylyl cyclase. J Neurosci 2002;22: 7931-7940.

- 152 Varga EV, Yamamura HI, Rubenzik MK, Stropova D, Navratilova E, Roeske WR: Molecular mechanisms of excitatory signaling upon chronic opioid agonist treatment. Life Sci 2003;74:299-311.

-153 Nestler EJ, Aghajanian GK: Molecular and cellular basis of addiction. Science 1997; 278:58-63.

-154 Chakrabarti S, Oppermann M, Gintzler AR: Chronic morphine induces the concomitant phosphorylation and altered association of multiple signaling proteins: a novel mechanism for modulating cell signaling. Proc Natl Acad Sci USA 2001;98: 4209-4214.

-155 Steiner D, Avidor-Reiss T, Schallmach E, Saya D, Vogel Z: Inhibition and superactivation of the calcium-stimulated isoforms of adenylyl cyclase: role of Gbetagamma dimers. J Mol Neurosci 2005;27:195-203.

-156 Avidor-Reiss T, Nevo I, Saya D, Bayewitch M, Vogel Z: Opiate-induced adenylyl cyclase superactivation is isozyme-specific. J Biol Chem 1997;272:5040-5047.

157 Li S, Lee ML, Bruchas MR, Chan GC, Storm DR, Chavkin C: Calmodulin-stimulated adenylyl cyclase gene deletion affects morphine responses. Mol Pharmacol 2006;70: 1742-1749.

- 158 Zachariou V, Liu R, Laplant Q, Xiao G, Renthal W, Chan GC, Storm DR, Aghajanian G, Nestler EJ: Distinct roles of adenylyl cyclases 1 and 8 in opiate dependence: behavioral, electrophysiological, and molecular studies. Biol Psychiatry 2008;63: 1013-1021.

159 Kim KS, Lee KW, Im JY, Yoo JY, Kim SW, Lee JK, Nestler EJ, Han PL: Adenylyl cyclase type 5 (AC5) is an essential mediator of morphine action. Proc Natl Acad Sci USA 2006;103:3908-3913.

- 160 Mansour A, Fox CA, Burke S, Meng F, Thompson RC, Akil H, Watson SJ: Mu, delta, and kappa opioid receptor mRNA expression in the rat CNS: an in situ hybridization study. J Comp Neurol 1994;350: 412-438.

-161 Yoshimura M, Wu PH, Hoffman PL, Tabakoff B: Overexpression of type 7 adenylyl cyclase in the mouse brain enhances acute and chronic actions of morphine. Mol Pharmacol 2000;58:1011-1016.

-162 Maas JW Jr, Vogt SK, Chan GC, Pineda VV, Storm DR, Muglia LJ: Calcium-stimulated adenylyl cyclases are critical modulators of neuronal ethanol sensitivity. J Neurosci 2005;25:4118-4126
163 Donohue T, Hoffman PL, Tabakoff B: Effect of ethanol on DARPP-32 phosphorylation in transgenic mice that express human type VII adenylyl cyclase in brain. Alcohol Clin Exp Res 2005;29:310-316.

164 Hellevuo K, Yoshimura M, Mons N, Hoffman PL, Cooper DM, Tabakoff B: The characterization of a novel human adenylyl cyclase which is present in brain and other tissues. J Biol Chem 1995;270:1158111589.

165 Tabakoff B, Hoffman PL, Lee JM, Saito T, Willard B, De Leon-Jones F: Differences in platelet enzyme activity between alcoholics and nonalcoholics. N Engl J Med 1988;318: 134-139.

166 Parsian A, Todd RD, Cloninger CR, Hoffman PL, Ovchinnikova L, Ikeda H, Tabakoff B: Platelet adenylyl cyclase activity in alcoholics and subtypes of alcoholics. WHO/ISBRA study clinical centers. Alcohol Clin Exp Res 1996;20:745-751.

167 Berghard A, Buck LB: Sensory transduction in vomeronasal neurons: evidence for G alpha o, G alpha i2, and adenylyl cyclase II as major components of a pheromone signaling cascade. J Neurosci 1996;16:909918

168 Wang Z, Balet Sindreu C, Li V, Nudelman A, Chan GC, Storm DR: Pheromone detection in male mice depends on signaling through the type 3 adenylyl cyclase in the main olfactory epithelium. J Neurosci 2006; 26:7375-7379.

169 Trinh K, Storm DR: Vomeronasal organ detects odorants in absence of signaling through main olfactory epithelium. Nat Neurosci 2003;6:519-525.

170 Livera G, Xie F, Garcia MA, Jaiswal B, Chen J, Law E, Storm DR, Conti M: Inactivation of the mouse adenylyl cyclase 3 gene disrupts male fertility and spermatozoon function. Mol Endocrinol 2005; 19:12771290.

171 Zou DJ, Chesler AT, Le Pichon CE, Kuznetsov A, Pei X, Hwang EL, Firestein S: Absence of adenylyl cyclase 3 perturbs peripheral olfactory projections in mice. J Neurosci 2007;27:6675-6683.

172 Col JA, Matsuo T, Storm DR, Rodriguez I: Adenylyl cyclase-dependent axonal targeting in the olfactory system. Development 2007; 134:2481-2489.

173 Wei J, Zhao AZ, Chan GC, Baker LP, Impey S, Beavo JA, Storm DR: Phosphorylation and inhibition of olfactory adenylyl cyclase by CaM kinase II in neurons: a mechanism for attenuation of olfactory signals. Neuron 1998;21:495-504.

174 Pepperl DJ, Shah-Basu S, VanLeeuwen D, Granneman JG, MacKenzie RG: Regulation of RGS mRNAs by cAMP in PC12 cells. Biochem Biophys Res Commun 1998;243: 52-55.
175 Beadling C, Druey KM, Richter G, Kehrl JH, Smith KA: Regulators of G protein signaling exhibit distinct patterns of gene expression and target $G$ protein specificity in human lymphocytes. J Immunol 1999;162: 2677-2682.

176 Defer N, Best-Belpomme M, Hanoune J: Tissue specificity and physiological relevance of various isoforms of adenylyl cyclase. Am J Physiol Renal Physiol 2000;279: F400-F416.

177 Mattick P, Parrington J, Odia E, Simpson A, Collins T, Terrar D: $\mathrm{Ca}^{2+}$-stimulated adenylyl cyclase isoform AC1 is preferentially expressed in guinea-pig sino-atrial node cells and modulates the I(f) pacemaker current. J Physiol 2007;582:1195-1203.

178 Tang T, Lai NC, Roth DM, Drumm J, Guo T, Lee KW, Han PL, Dalton N, Gao MH: Adenylyl cyclase type $\mathrm{V}$ deletion increases basal left ventricular function and reduces left ventricular contractile responsiveness to beta-adrenergic stimulation. Basic Res Cardiol 2006;101:117-126.

179 Iwase M, Uechi M, Vatner DE, Asai K, Shannon RP, Kudej RK, Wagner TE, Wight DC, Patrick TA, Ishikawa Y, Homcy CJ, Vatner SF: Cardiomyopathy induced by cardiac Gs alpha overexpression. Am J Physiol Heart Circ Physiol 1997;272:H585H589.

180 Engelhardt S, Hein L, Wiesmann F, Lohse MJ: Progressive hypertrophy and heart failure in betal-adrenergic receptor transgenic mice. Proc Natl Acad Sci USA 1999;96: 7059-7064

-181 Antos CL, Frey N, Marx SO, Reiken S, Gaburjakova M, Richardson JA, Marks AR, Olson EN: Dilated cardiomyopathy and sudden death resulting from constitutive activation of protein kinase A. Circ Res 2001;89:997-1004.

$>182$ Okumura S, Takagi G, Kawabe J, Yang G, Lee MC, Hong C, Liu J, Vatner DE, Sadoshima J, Vatner SF, Ishikawa Y: Disruption of type 5 adenylyl cyclase gene preserves cardiac function against pressure overload. Proc Natl Acad Sci USA 2003;100:99869990.

183 Yan L, Vatner DE, O’Connor JP, Ivessa A, Ge H, Chen W, Hirotani S, Ishikawa Y, Sadoshima J, Vatner SF: Type 5 adenylyl cyclase disruption increases longevity and protects against stress. Cell 2007;130:247258.

184 Espinasse I, Iourgenko V, Defer N, Samson F, Hanoune J, Mercadier JJ: Type V, but not type VI, adenylyl cyclase mRNA accumulates in the rat heart during ontogenic development. Correlation with increased global adenylyl cyclase activity. J Mol Cell Cardiol 1995;27:1789-1795. 
185 Tobise K, Ishikawa Y, Holmer SR, Im MJ, Newell JB, Yoshie H, Fujita M, Susannie EE, Homcy CJ: Changes in type VI adenylyl cyclase isoform expression correlate with a decreased capacity for cAMP generation in the aging ventricle. Circ Res 1994;74:596603.

186 Tang T, Gao MH, Lai NC, Firth AL, Takahashi T, Guo T, Yuan JX, Roth DM, Hammond HK: Adenylyl cyclase type 6 deletion decreases left ventricular function via impaired calcium handling. Circulation 2008; 117:61-69.

187 Tepe NM, Lorenz JN, Yatani A, Dash R, Kranias EG, Dorn GW, 2nd, Liggett SB: Altering the receptor-effector ratio by transgenic overexpression of type $\mathrm{V}$ adenylyl cyclase: enhanced basal catalytic activity and function without increased cardiomyocyte beta-adrenergic signalling. Biochemistry 1999;38:16706-16713.

188 Esposito G, Perrino C, Ozaki T, Takaoka H, Defer N, Petretta MP, De Angelis MC, Mao L, Hanoune J, Rockman HA, Chiariello M: Increased myocardial contractility and enhanced exercise function in transgenic mice overexpressing either adenylyl cyclase 5 or 8. Basic Res Cardiol 2008;103:22-30.

189 Gao MH, Lai NC, Roth DM, Zhou J, Zhu J, Anzai T, Dalton N, Hammond HK: Adenylylcyclase increases responsiveness to catecholamine stimulation in transgenic mice. Circulation 1999;99:1618-1622.
190 Lai NC, Roth DM, Gao MH, Fine S, Head BP, Zhu J, McKirnan MD, Kwong C, Dalton N, Urasawa K, Roth DA, Hammond $\mathrm{HK}$ : Intracoronary delivery of adenovirus encoding adenylyl cyclase VI increases left ventricular function and camp-generating capacity. Circulation 2000;102:23962401.

191 Lipskaia L, Defer N, Esposito G, Hajar I, Garel MC, Rockman HA, Hanoune J: Enhanced cardiac function in transgenic mice expressing a $\mathrm{Ca}(2+)$-stimulated adenylyl cyclase. Circ Res 2000;86:795-801.

192 Georget M, Mateo P, Vandecasteele G, Jurevicius J, Lipskaia L, Defer N, Hanoune J, Hoerter J, Fischmeister R: Augmentation of cardiac contractility with no change in $\mathrm{L}$ type $\mathrm{Ca}^{2+}$ current in transgenic mice with a cardiac-directed expression of the human adenylyl cyclase type 8 (AC8). FASEB J 2002;16:1636-1638.

193 Tepe NM, Liggett SB: Transgenic replace ment of type $\mathrm{V}$ adenylyl cyclase identifies a critical mechanism of beta-adrenergic receptor dysfunction in the G alpha q overexpressing mouse. FEBS Lett 1999;458:236240 .
194 Roth DM, Gao MH, Lai NC, Drumm J, Dalton N, Zhou JY, Zhu J, Entrikin D, Hammond HK: Cardiac-directed adenylyl cyclase expression improves heart function in murine cardiomyopathy. Circulation 1999; 99:3099-3102.

195 Roth DM, Bayat H, Drumm JD, Gao MH, Swaney JS, Ander A, Hammond HK: Adenylyl cyclase increases survival in cardiomyopathy. Circulation 2002;105:19891994.

196 Lai NC, Roth DM, Gao MH, Tang T, Dalton N, Lai YY, Spellman M, Clopton P, Hammond $\mathrm{HK}$ : Intracoronary adenovirus encoding adenylyl cyclase VI increases left ventricular function in heart failure. Circulation 2004;110:330-336.

197 Buxton IL, Brunton LL: Compartments of cyclic amp and protein kinase in mammalian cardiomyocytes. J Biol Chem 1983;258: 10233-10239.

198 Jurevicius J, Fischmeister R: Camp compartmentation is responsible for a local activation of cardiac $\mathrm{Ca}^{2+}$ channels by betaadrenergic agonists. Proc Natl Acad Sci USA 1996;93:295-299.

199 Huang Y, Lemieux MJ, Song J, Auer M, Wang DN: Structure and mechanism of the glycerol-3-phosphate transporter from Escherichia coli. Science 2003;301:616620 . 